\title{
Convergence and Divergence of Sugar and Cytokinin Signaling in Plant Development
}

\author{
Ming Wang ${ }^{1,2}$, José Le Gourrierec ${ }^{1}$, Fuchao Jiao ${ }^{2}$, Sabine Demotes-Mainard ${ }^{1}{ }^{(D}$, Maria-Dolores Perez-Garcia ${ }^{1}(\mathbb{D}$, \\ Laurent Ogé ${ }^{1}$, Latifa Hamama ${ }^{1}$, Laurent Crespel ${ }^{1}$, Jessica Bertheloot ${ }^{1} \mathbb{\infty}$, Jingtang Chen ${ }^{2}$, Philippe Grappin ${ }^{1}$ \\ and Soulaiman Sakr ${ }^{1, *(1)}$ \\ 1 Institut Agro, University of Angers INRAE, IRHS, SFR QUASAV, F-49000 Angers, France; \\ ming.wang@qau.edu.cn (M.W.); jose.gentilhomme@univ-angers.fr (J.L.G.); \\ sabine.demotes-mainard@inrae.fr (S.D.-M.); maria-dolores.perez-garcia@agrocampus-ouest.fr (M.-D.P.-G.); \\ laurent.oge@agrocampus-ouest.fr (L.O.); latifa.hamama@agrocampus-ouest.fr (L.H.); \\ laurent.crespel@agrocampus-ouest.fr (L.C.); jessica.bertheloot@inra.fr (J.B.); \\ philippe.grappin@agrocampus-ouest.fr (P.G.) \\ 2 College of Agronomy, Qingdao Agricultural University, Qingdao 266109, China; fuchao.jiao@qau.edu.cn (F.J.); \\ chenjingtang@126.com (J.C.) \\ * Correspondence: soulaiman.sakr@agrocampus-ouest.fr
}

check for updates

Citation: Wang, M.; Le Gourrierec, J.; Jiao, F.; Demotes-Mainard, S.; Perez-Garcia, M.-D.; Ogé, L.; Hamama, L.; Crespel, L.; Bertheloot, J.; Chen, J.; et al. Convergence and Divergence of Sugar and Cytokinin Signaling in Plant Development. Int. J. Mol. Sci. 2021, 22, 1282. https://doi.org/10.3390/ ijms22031282

Academic Editor: Iwona Morkunas Received: 23 December 2020

Accepted: 24 January 2021

Published: 28 January 2021

Publisher's Note: MDPI stays neutral with regard to jurisdictional claims in published maps and institutional affiliations.

Copyright: (c) 2021 by the authors. Licensee MDPI, Basel, Switzerland. This article is an open access article distributed under the terms and conditions of the Creative Commons Attribution (CC BY) license (https:/ / creativecommons.org/licenses/by/ $4.0 /)$.

\begin{abstract}
Plants adjust their growth and development through a sophisticated regulatory system integrating endogenous and exogenous cues. Many of them rely on intricate crosstalk between nutrients and hormones, an effective way of coupling nutritional and developmental information and ensuring plant survival. Sugars in their different forms such as sucrose, glucose, fructose and trehalose-6-P and the hormone family of cytokinins (CKs) are major regulators of the shoot and root functioning throughout the plant life cycle. While their individual roles have been extensively investigated, their combined effects have unexpectedly received little attention, resulting in many gaps in current knowledge. The present review provides an overview of the relationship between sugars and CKs signaling in the main developmental transition during the plant lifecycle, including seed development, germination, seedling establishment, root and shoot branching, leaf senescence, and flowering. These new insights highlight the diversity and the complexity of the crosstalk between sugars and CKs and raise several questions that will open onto further investigations of these regulation networks orchestrating plant growth and development.
\end{abstract}

Keywords: nutrient; hormones; development; seeds; flowering; branching senescence; meristem; source-sink relationship

\section{Introduction}

The regulation of plant growth and development is crucial for yield and resistance to abiotic and biotic constraints, which relies on fine-tuned interactions between nutrients and hormones, influenced by environmental inputs. Among these central regulators, sugars and cytokinins (CKs) play predominant roles while operating synergistically, antagonistically and sometimes independently to shape the final reaction of the plant. Sugars growth-related metabolic activity and as signaling entities that drive a wide array of mechanisms throughout the plant life cycle [1-5]. Briefly, sugar signaling is intimately linked to developmental stages, hormonal signaling and environmental conditions, and thereby is an integrative part of plant growth control [6-11]. Plants can sense a diversity of soluble sugars such as sucrose, glucose, fructose and trehalose-6-phosphate (T6P). Sophisticated sugar sensing networks have been identified, including hexokinase (HXK), Regulator of G-protein signaling (RGS1), and two main sensors of nutrients and energy status: sucrose-nonfermentation1-related protein kinase1 (SnRK1) and target of rapamycin (TOR) kinase [12-18]. 
CKs are a group of adenine derivatives involved in many central processes in plants, such as development of vasculature, differentiation of embryonic cells, maintenance of meristematic cells, shoot formation and leaf senescence delay [19-23]. There are two types of CKs: adenine-type cytokinins represented by kinetin, zeatin, and 6-benzylaminopurine, and phenylurea-type cytokinins like diphenylurea and thidiazuron. Most adenine-type cytokinins are synthesized in roots. Cambium and other actively dividing tissues also synthesize CKs. CKs are viewed as one of the major long-distance root-to-shoot messengers [24]. Their biosynthesis depends on the activity of adenosine phosphate-isopentenyltransferases (IPTs). Trans-zeatin is the most abundant form of CK in plants [25]. Initially identified in rice, Lonely Guy (LOG), cytokinin nucleoside 54-monophosphate phosphoribohydrolases, are involved in direct CK production [26,27]. CKs primarily regulate gene expression through a phosphotransfer signaling cascade. This cascade is initiated by histidine kinase cytokinin receptors, Arabidopsis Histidine Kinase2 (AHK2), AHK3 and AHK4, that located in the endoplasmic reticulum membrane, and completed by cytosolic histidine phosphotransfer proteins (AHP) [28]. AHPs shuttle between the cytosol and the nucleus and transfer phosphate to nuclear response regulators (Arabidopsis Response Regulators, ARRs) $[19,23]$ that fall into two classes: type-A and type-B ARRs are negative and positive regulators of CK signaling, respectively.

Sugars and CKs are individually viewed as major players in many aspects of plant biology. Yet, their crosstalk has not been systematically investigated, hence many gaps in current knowledge. Moreover, the available results underline that the crosstalk is very complex and varies at least according to the nature of the organ and the physiological process. This review aims to underline the interactions between sugars and CKs based on their individual and combined roles in the regulation of key developmental processes throughout the plant life cycle. Based on the results derived from different plant species, sugars and CKs seem to act synergistically to take over the seedling emergency, shoot meristem activity, shoot branching and flowering while doing antagonistically as strongly suggested for seed germination, root meristematic activity, and even demonstrated for root branching and leaf senescence (Figure 1). Here, the main results are discussed, potential integrators of this crosstalk are proposed, and further lines of research are highlighted.

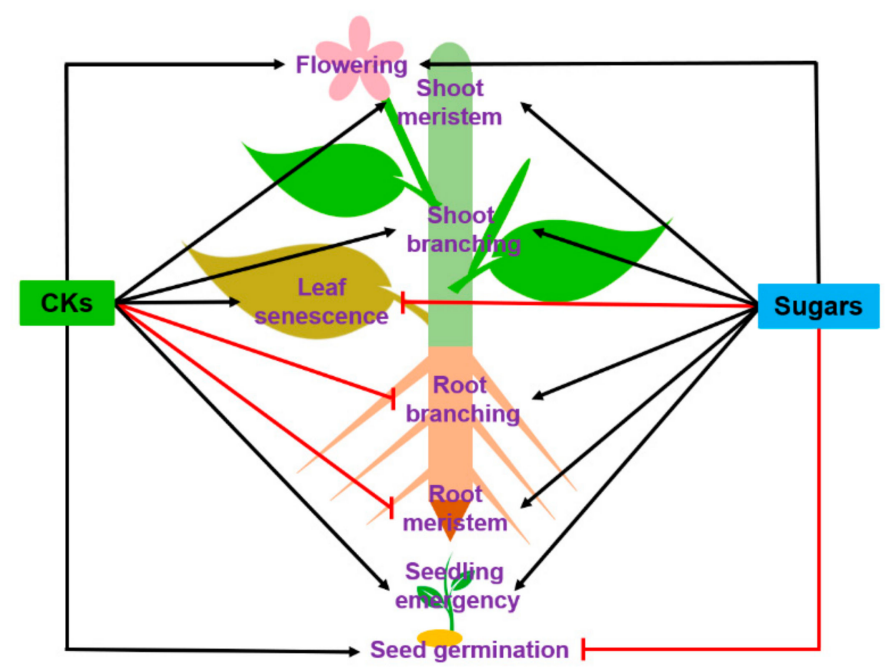

Figure 1. Relationship between sugars and cytokinins (CKs) in the main plant developmental processes, including seed development, germination, seedling establishment, root and shoot branching, leaf senescence, and flowering. The black arrows indicate stimulation or positive effect, and the red lines mean repression or negative effect. This model results from a compilation of studies carried out on different model plants (see references and description in the text). 


\section{Seed Development, Germination and Seedling Establishment}

Seed formation, as well as the seed-to-young-seedling transition through germination, involves sugar and hormone signaling [29,30]. Even though common key players have been identified in the seed response to sugars and CKs, their molecular interaction remains speculative.

\subsection{Seed Development}

Seed development covers morphogenesis phases characterized by active cell division and embryonic organ formation and a maturation phase during which storage nutrients accumulate in cotyledons and/or endosperm tissues, with a transfer of reserves between these two compartments [31]. In this latter phase, the embryo acquires tolerance to desiccation and a dormancy state before dispersal in the environment. Dormancy allows the seed to cope with its adverse environment and secures the transition to a new life cycle. Previous works have reported the contribution of sugars and CKs in the control of seed development $[32,33]$. In cotyledons of Vicia faba, a high glucose-to-sucrose ratio is correlated with cell division during the morphogenesis phase, whereas an increasing sucrose-to-glucose ratio marks the sink-source transition to the storage phase [34]. The high glucose gradient is related to both high cell-wall-bound invertase (CWINV) expression in the maternal seed coat and hexose transporter (VfSTP1) expression in the embryonic epidermal cells $[35,36]$. Analyses of the CWINV-deficient mutant miniature1 ( $m n 1$ ), impaired in endosperm development in maize caryopses, provide evidence that CWINV also contributes to CK-dependent cell proliferation during the developmental transition to the storage phase [37-39]. Such a $\mathrm{CK}$ effect may operate directly on cell cycle-related genes $(\mathrm{CycD} 3)$ and indirectly through (CWINV2)-mediated sugar signaling [37,40,41]. Nevertheless, the seemingly contradictory phenotype of the CK-receptor-defective triple mutant ahk 2 ahk 3 cre1 exhibiting greater seed size points to the complexity of the regulatory network [42]. Understanding how CKs contribute to seed development will require considering the different levels of regulation of CK metabolisms, such as the spatiotemporal accumulation and transport of CKs in seed tissues, the dynamics of their biosynthesis (IPT) and inactivation (CKX), and their perception. The transition from cell division and expansion (seed morphogenesis) to storage activity (seed maturation phase) is associated with downregulated CWINV and IPT expression $[43,44]$. At this stage, sugars serve for seed storage accumulation by mediating sucrose synthase induction for starch biosynthesis in maize kernels [33,45] or gibberellic acid (GA) dependent $\alpha$-amylase induction for storage remobilization in barley embryos [46]. Such sugar-dependent regulation takes place at the transcriptional and post-transcriptional levels [2]. The role of sugars in seed maturation could be complex and partially mediated through T6P, considered as a proxy for sucrose availability in plants [47], and SnRK1 [48]. Sucrose positively regulates T6P accumulation in wheat at the seed pre-filling stage [49], and its exogenous application stimulates seed filling and yield [50]. Accordingly, Arabidopsis seeds of the mutant tps1 (Trehalose-6-phosphate synthase 1) fail to proceed towards the maturation phase $[51,52]$. In pea, SnRK1 deficiency hinders the maturation and storage activity $[53,54]$. Accordingly, SnRK1 induces abscisic acid (ABA) synthesis and signaling and the C/S1-group bZIP signaling pathways associated with carbon starvation $[55,56]$. This regulation is mediated by pFUS3 (The Arabidopsis B3-domain transcription factor FUSCA3) phosphorylation, known to control ABA responses during seed maturation and dormancy [57]. Transcriptomic comparison of CK metabolism and signaling in dormant and non-dormant wheat seeds $[58,59]$ highlights that CK controls the activity of many genes involved in seed dormancy. The interactions of CKs with ABA metabolism and signaling during seed maturation need to be further investigated and compared with sugar signaling mediated at least by the T6P and SnRK1 pathways.

\subsection{Seed Germination and Seedling Establishment}

The carbon stored in the mature seed will be remobilized during germination to ensure seedling establishment before becoming heterotrophic. Seed germination is accomplished 
when the radicle protrudes through the outer layers of the embryo, i.e., the endosperm and the teguments [60]. The related cellular and metabolic events are orchestrated by complex signaling crosstalk involving the hormones ABA and GA, well known for their role in inhibiting and inducing germination, respectively [61]. Sugars released from the GAmediated hydrolysis of storage compounds and cell wall loosening serve as osmotically active solutes for radicle cell expansion. These sugars are potentially used as central signals of the seed's $C$ status and are also a source of $C$ for seedling growth during the transition to autotrophy. Genetic and molecular analysis revealed a possible control of germination by glucose based on HXK1-dependent and independent pathways and the T6P pathway, interacting with different hormonal pathways [29]. Many reports also showed that CKs contribute to the control of seed germination [42]. However, their interactions with glucose are poorly documented. On the whole, glucose and CKs are likely to operate antagonistically at different steps of the ABA biosynthesis and signaling pathways (Figure 2). The contribution of glucose to the control of seed germination has long been established and proven to be a concentration-dependent signal [62-64]. Exogenous supply of high glucose contents delays seed germination through positive regulation of ABA synthesis, accumulation and signaling [65-68]. At lower concentrations, glucose stimulates germination by inducing ABA catabolism [69]. In germinating seeds, high glucose supply upregulates two ABA biosynthesis genes (NCED3 and $A B A 2$ ) through the G Protein Alpha subunit AtGPA1 and the Regulator of G-protein Signaling AtRGS1, via an HXK1-independent channel [70-72]. Glucose also repressed-the positive regulator of seed germination AtGASA6 via an HXK1-dependent pathway [73,74]. AtGASA6 acts as an integrator of ABI5-dependent ABA signaling and RGL2-dependent GA signaling [73]. Therefore, a high level of T6P promotes seed germination by decreasing seed sensitivity to glucose and ABA [75-77]. In sum, the inhibition of seed germination under excessive glucose supply conditions may be due to the activation of the ABA signaling pathway and an imbalance in sugars/T6P [56].

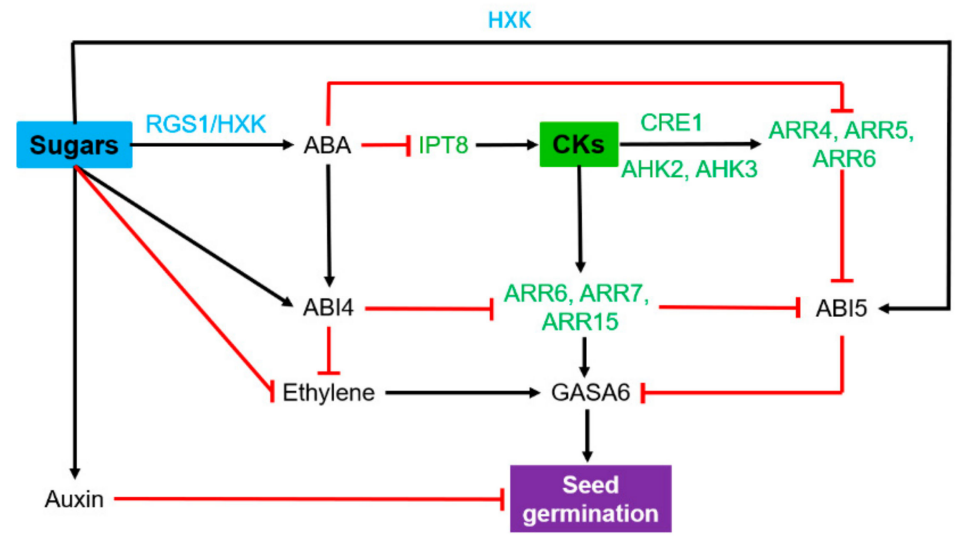

Figure 2. Antagonistic effect of sugars and cytokinins (CKs) on seed germination. Blue stands for players of sugar signaling pathways, and green highlights genes involved in CK synthesis or signaling pathways. Black arrows and red lines indicate stimulatory and inhibitory effects, respectively. ABI, abscisic acid insensitive; AHK, Arabidopsis histidine kinase; ARR, Arabidopsis response regulator; CRE, cytokinin response; GASA, gibberellic acid-stimulated Arabidopsis; HXK, hexokinase, IPT: isopentenyl transferase; RGS, regulator of G-protein signaling. This model results from a compilation of studies carried out on different model plants (see references and description in the text).

The CKs are described to stimulate seed germination by an antagonistic effect on ABA signaling [78-80]. In germinating seeds, increasing levels of CKs induce the expression of type-A ARRs (ARR4, ARR5 and ARR6) that inactivate the ABI5-mediated inhibition of germination [81,82] whereas glucose enhances ABI5 transcription [83] (Figure 2). In turn, $\mathrm{ABA}$ intake represses $\mathrm{CK}$ biosynthetic genes such as AtIPT8 and CK signaling genes such as type-A ARRs, and during seed dormancy, ABA signaling, including ABA receptor 
Pyrabactin Resistance (PYR/PYL), SnRK2s and ABI4, downregulates type-A ARRs [84]. In dormant seeds, high ABA levels positively regulate ABI4, which inhibits the expression of ARR6, ARR7 and ARR15. Either, Arabidopsis CK-receptor mutants exhibit a reduced dormancy phenotype, and distinct CK-mediated seed germination regulation pathways seem to exist [42]. In germinating seeds, many other regulatory pathways respond to different forms of sugar signals. The exogenous sugar-dependent inhibition of seed germination is also regulated by the sucrose transporter SUT4/Cyb5-2-mediated signaling pathway, independently of the ABA (ABI2/ABI4/ABI5)-mediated signaling pathway [85]. CK biosynthesis is noticeably concomitant with SUT gene expression during pea seed germination. Therefore, we may wonder whether sugar transporters could be a convergent target of sugars and CKs during this process [86].

Interestingly, promoters of the senescence-associated genes SAG12 and SAG13 are inducible in the tomato seed micropylar endosperm [87], suggesting that a senescing mechanism known to be stimulated by HXK1-dependent sugar signaling (see Leaf Senescence Section 5) could facilitate radicle protrusion. Ectopic expression of the IPT gene through SAG12 and SAG13 promoters delayed endosperm senescence and germination, suggesting that potential CK synthesis in the endosperm can antagonize the HXK-dependent sugar senescing mechanism to negatively control germination. Therefore, CKs could be perceived differently in a tissue-dependent manner during seed germination.

The crosstalk between sugars and CKs in the control of germination remains very partially documented, and available results foresee very intricate mechanisms. All the present results support antagonistic effects of glucose and CKs throughout the germination process, which precedes seedling growth considered as a post-germinative phase.

\subsection{Seedling Development}

Upon radicle protrusion through the seed coat, the first post-germinative events initiate seedling growth through hypocotyl elongation and root meristem development before the activation of the photosynthesis machinery. Hypocotyl elongation occurs in darkness and is fueled by $\mathrm{C}$ issued from the hydrolysis and mobilization of seed storage compounds. The shoot apical meristem (SAM) is characterized by a heterotrophic metabolism, while the development of the root apical meristem (RAM) occurs only under light conditions and is controlled by cotyledon-derived photosynthetic sucrose that acts as a long-distance signal [88].

CK and glucose signaling are involved in controlling different aspects of seedling growth and development, with auxin signaling components as downstream targets. From a physiological point of view, both glucose and CKs could control radicle growth in light conditions, hypocotyl length in darkness, chlorophyll and anthocyanin contents [89]. CKs interact with glucose via an HXK1-dependent pathway for the control of radicle and hypocotyl elongation $[30,90]$. SnRK1 overexpression can delay seed germination and increases sensitivity to glucose and ABA during seedling establishment [91]. When glucose is supplied to seedlings, T6P acts antagonistically to SnRK1 by inhibiting ABA synthesis and signaling and, in turn, the seed sensitivity to glucose [92]. Noteworthily, CKs antagonize ABA signaling by inhibiting SnRK2 activity via type-B ARRs and thus promote seedling establishment [93].

\section{Meristem Establishment and Functioning}

Sugars and CKs are fully part of the regulation of the dynamic balance between cell division and cell differentiation, which determines organ shape and size. Sugars can activate the expression of key cell cycle regulators, such as cyclin-dependent kinases (CDKs) and their interacting cyclins (CYCs), promoting the G2/mitosis transition in Arabidopsis seedling meristematic tissues [88,94-97]. CK signaling contributes to the stimulation of cell division and meristem initiation/formation $[98,99]$. 


\subsection{Root Apical Meristems}

The root system consists of two principal root-types: the primary root (PR), which is formed embryonically and secondary roots, which form post-embryonically [100]. Glucose influence root meristematic activity through many pathways, including the macroautophagy/autophagy degradation pathway, which acts downstream of SnRK1 and TOR kinase [101]. High concentrations of glucose reduce the size of the root meristem zone via ABI5, which represses the auxin efflux carrier PIN1 required for auxin accumulation in the meristem (Figure 3) [102]. Either, mounting evidence also indicates that SnRK1 and ABA can control root meristem activity cooper actively [103-105]. Overexpression of SnRK1.1 results in an ABA-hypersensitive phenotype [104] due to its interaction with the regulator of ABA response PP2C phosphatase protein [106-108]. ABI5, the main node of the glucose and ABA pathways, is directly phosphorylated by SnRK1 [56,109,110]. Glucose induces $A B I 5$ expression, which reduces the size of the root meristem zone. ABI5 can coordinate and adjust physiological and metabolic demands with growth, but also interact with TOR kinase-a highly conserved eukaryotic phosphatidylinositol-3-kinase-related kinase-through TAP46 (2A Phosphatase Associated Protein of 46 KD) to influence the ABI5 signaling pathway negatively [111-113]. TOR-kinase also plays a major role in the regulation of growth and metabolism in plants [114]. Glucose-driven TOR-kinase signaling regulates root meristem activation independently of hormonal and hexokinase signaling pathways and involves the upregulation of the elongation factor E2Fa [115]. In response to metabolic demands, the tonoplast sugar transporter (TST) imports sucrose, fructose and glucose into the root vacuoles to maintain cytosolic sugar homeostasis [116]. Yet Another Kinase (YAK) acts as a member of the dual-specificity tyrosine phosphorylation-regulated kinase and may be involved downstream of this TOR signaling-mediated control of root meristem activity in Arabidopsis [117].

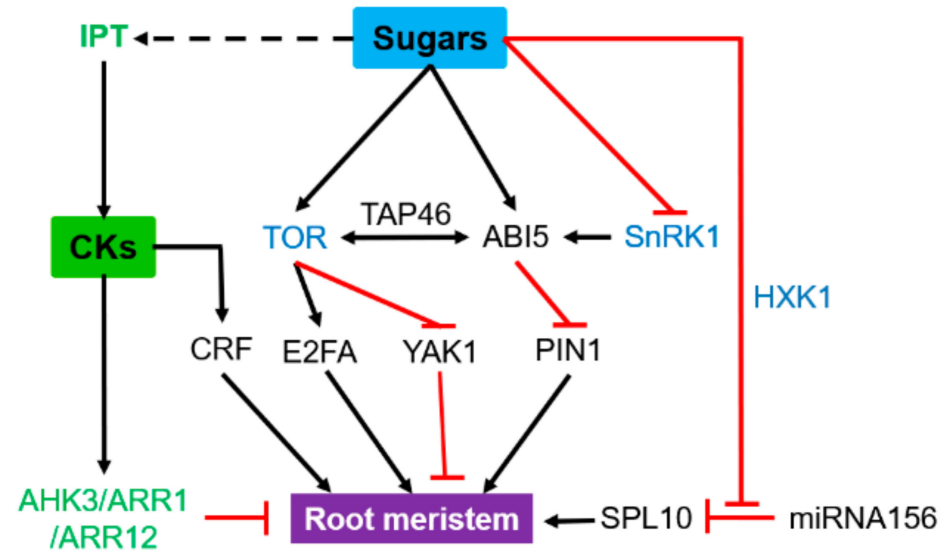

Figure 3. Antagonistic effect of sugars and cytokinins (CKs) on the functioning of the root meristem. Blue indicates sugar signaling pathways, and green highlights genes involved in CK synthesis or signaling pathways. Black arrows and red lines indicate stimulatory and inhibitory effects, respectively. Solid line, direct effect; dotted indirect effect. ABI5, abscisic acid insensitive 5; AHK3, Arabidopsis histidine kinase 3; ARR, Arabidopsis response regulator; CRF, cytokinin response factor; HXK1, hexokinase 1; E2FA, elongation 2 factor A; IPT, isopentenyl transferase; PIN1, PIN-FORMED 1; SnRK1, SNF1-related kinase1; SPL10, Squamosa Promoter Binding Protein-Like 10; TAP46, type 2A phosphatase associated protein of 46KD; TOR, target of rapamycin protein kinase; YAK1: Yet Another Kinase. This model results from a compilation of studies carried out on different model plants (see references and description in the text).

CKs are essential to promote cell differentiation in the root meristem [118-120]. This is due to trans-zeatin, whose accumulation slows down the root growth rate and the cell transition to elongation, leading to prolonged mitotic cycles [121]. Mutants defective in all CK receptors display severely reduced sizes of their shoot and root meris- 
tems $[122,123]$. This CK-dependent reduction of the root meristem size could involve a two-component receptor histidine kinase and type A-ARR transcription factor, such as AHK3/ARR1, AHK3/ARR12, that regulates the rate of meristematic cell differentiation (Figure 3) [123-125]. The Squamosa Promoter Binding Protein-Like (SPL) transcription factor is one of the targets of microRNA156 (miRNA156). miRNA156 and SPL have opposing expression patterns; high miRNA156 levels induce reduced root meristem size, while overexpression of SPL10 increases it [126]. Furthermore, meristem activity is regulated by SPL10, probably through the reduction of CK responses via the modulation of type-B Arabidopsis Response Regulator1 (ARR1) expression. This points to a cooperative regulation of root meristem activity by CK responses via miRNA156-targeted SPL10 [126]. Given that miRNA156 is a central component of sugar signaling [127], it will be of high interest to investigate whether sugars could take part in this regulatory network. CKs also cooperate with other hormones to regulate root meristem development. In Arabidopsis roots, the IAA3/Short Hypocotyl 2 (SHY2) gene is an important hub of the crosstalk between CKs, auxin and brassinosteroids (BRs) [128]. This calls for investigating its regulation by sugars. CK response factors (CRFs) are a group of related AP2/ERF transcription factors transcriptionally induced by CKs [129]. Overexpression of CRFs in Arabidopsis results in a larger root apical meristem. Disruption of CRFs was accompanied by low sensitivity to CKs in a root elongation assay, along with a reduced expression level of ARRs and of the homeobox gene STIMPY (STIP or WOX9) required for root and shoot apical meristem maintenance [19]. Although being acted antagonistically to regulate root meristem activity, additional investigations are required to bring the first mechanistic insights associated with molecular integrators involved in sugars and CKs crosstalk.

\subsection{Shoot Meristem}

The shoot meristem contains a central zone (CZ) that harbors pluripotent stem cells and surrounding regions in which cells start to differentiate, and organ primordia are initiated. Sucrose and Glucose have long been known to promote meristem growth $[1,130,131]$, and this effect could be mediated by the upregulation of CDKs and CYCs expression, which are required for the G1/S and G2/M transitions (Figure 4) [97,132]. While glucose signaling is sufficient to activate TOR kinase in root apexes, both glucose and light signals are required for TOR activation in shoot apices [133]. SnRK1 is expressed in the meristem and young leaf primordia; its low activity is required for CK biosynthesis [54,56,134], hence a link between nutrient/energy availability and CK production. In contrast with their role in roots, CKs promote shoot cell division through the regulation of a variety of key genes related to plant meristem activity and are essential to maintain undifferentiated cells $[119,135,136]$. The CLAVATA (CLV) ligand-receptor system and two transcription factors, SHOOTMERISTEM-LESS (STM) and WUSCHEL (WUS), are involved in meristem growth [137-139]. WUS, a positive regulator of stem cell proliferation, directly downregulates several type-A ARR transcription factors (ARR5, ARR6, ARR7 and ARR15), which act in the negative feedback loop of CK signaling (Figure 4) [140,141]. More interestingly, CK signaling precedes the de novo expression of WUS in the leaf axil to promote axillary meristem initiation via the direct binding of the type-B ARR transcription factor to the WUS promoter (Figure 4) [98]. Moreover, CK signaling can activate the meristem and maintain its fate by inducing STIMPY expression in meristematic tissues [142,143]. The IPT and LONELY GUY (LOG) genes, which encode a novel CK-activating enzyme operating in the final step of bioactive CK synthesis, are both pivotal for the conversion of CK hormone precursors into active hormones within the shoot meristem [26,136]. In line with this, CK deficiency mutants display low activity of the vegetative and floral shoot apical meristems [144]. However, an opposite effect has been reported in Azolla as compared to Arabidopsis [145]. 


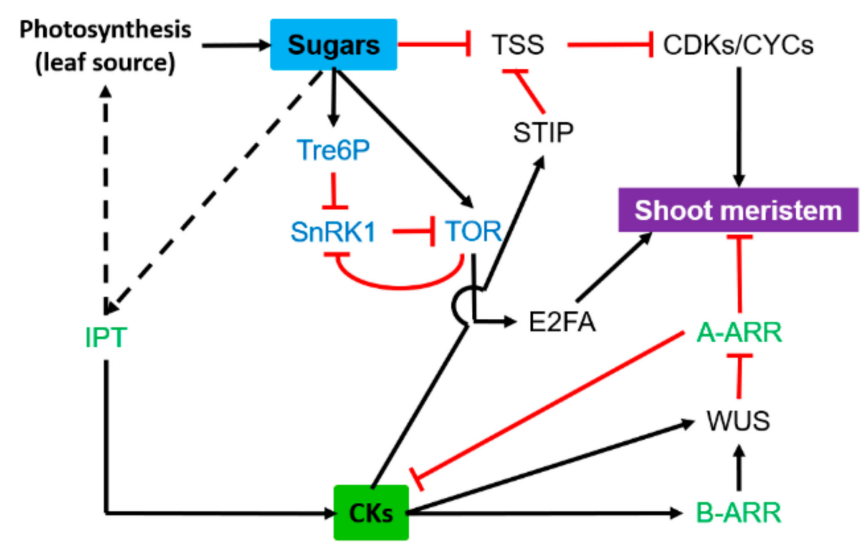

Figure 4. Synergetic effect of sugars and cytokinins (CKs) on the functioning of the shoot meristem. Blue indicates sugar signaling pathways, and green highlights genes involved in CK synthesis or signaling pathways. Black arrows and red lines indicate stimulatory and inhibitory effects, respectively. Solid line, direct effect; dotted indirect effect. A-ARR, type-A Arabidopsis response regulator; $\mathrm{B}-\mathrm{ARR}$, type-B Arabidopsis response regulator; $\mathrm{CRF}$, cytokinin response factor; $\mathrm{CDKs}$, cyclindependent kinases; CYCs, cyclins; E2FA, elongation 2 factor A; IPT, isopentenyl transferase; SnRK1, SNF1-related kinase 1; TOR, target of rapamycin protein kinase; Tre6P, trehalose-6-phosphate; TSS, TPR-DOMAIN SUPPRESSOR OF STIMP; WUS, WUSCHEL. This model results from a compilation of studies carried out on different model plants (see references and description in the text).

Transcriptomic analysis identified that glucose could stimulate CK accumulation through the induction of IPT3 expression and the repression of cytokinin oxidase (CKX4) and also control the expression of $76 \%$ of CK-regulated genes at the whole-genome level in Arabidopsis seedlings [90]. This study highlights that the interaction between glucose and CKs plays a key and synergistic role in shoot meristem activity. Additional work would be required to identify the main convergent node of the crosstalk between sugars and CKs. One approach would be to use the promoter of some common genes such as CYCs, CDKs to identify the upstream regulators.

\section{Root and Shoot Branching}

Plants comprise two distinct parts: (i) the shoot system for photosynthesis and reproductive functions, and (ii) the root system for water and nutrient uptake from the soil and anchorage. These two parts have evolved a complex branching strategy to increase their total surface area, ensuring a better adjustment of plants to their abiotic and biotic environments.

\subsection{Lateral Root Growth}

Shoot branches are formed by an actively dividing shoot meristem, whereas lateral roots are derived from the pericycle, located beyond the root subapical meristem zone [146]. Auxin regulates lateral roots (LRs) positioning, which determines the spatial distribution of lateral root primordia and LRs along with primary roots [147]. Auxin also regulates root outgrowth and LRs emergence through interaction with sugars and CKs. Sugars promote lateral root initiation using different pathways that are not always associated with auxin $[148,149]$. Map-based cloning revealed that a neutral invertase gene (AtCYT$I N V 1$ ) had a significant influence on lateral root development by controlling the hexose concentration within cells [150]. Photosynthetically generated sugars induce AtIPT3 and CYP735A expression to promote CK accumulation in roots [151]. This effect operates through the heterotrimeric G-protein complex (hexokinase-independent pathway), which regulates auxin distribution in the root and thereby induces lateral root formation [149]. More precisely, WOX7, a member of the WUSCHEL related homeobox (WOX) family of transcription factors, plays a major role in coupling lateral root development with the sugar status in plants [146]. WOX7 acts as a transcriptional repressor in lateral root 
development. Genetic, physiological, transcriptomic and grafting approaches evidenced that $C$-Terminally Encoded Peptide Receptor 1 (CEPR1) inhibited lateral root growth in response to sugars (including sucrose) and elevated light intensity [152].

CKs represses lateral root initiation and promote lateral root elongation [153-155]. They block cell cycling in the pericycle founder cells at the G2/M transition phase [156] and then disturb lateral root initiation in plants [157], confirming that the earliest stages of lateral root formation are very sensitive to the inhibitory effect of CKs [158]. Cytokinin Response Factor2 (CRF2), a component of the CK signaling pathway, plays an important role in regulating Arabidopsis lateral root initiation [159]. In Arabidopsis again, the mutation of $C Y P 735 \mathrm{~A}$ genes required for trans-zeatin biosynthesis causes strong defects in lateral root positioning, indicating a determining role for CK metabolites in the regulation of lateral root initiation [160].

The crosstalk between CKs and sugars also regulates root branching (Figure 4). Combined analysis in roots of grafted apple revealed that root growth and development of rootstocks were mainly influenced by the sugar metabolism, auxin, and CK signaling [161]. Furthermore, the crosstalk between glucose and CKs regulates root development in Arabidopsis [89]. These authors showed that CKs interact with glucose via an HXK1-dependent pathway for root length control. Wild-type (WT) roots cannot elongate without glucose, but roots elongate even in the absence of glucose in the CK-receptor mutant Arabidopsis Histidine Kinase4 (ahk4) and type-B ARR triple mutant arr1 (Arabidopsis Response Regulator1), arr10, arr11 compared with the WT. Although 60 genes related to root growth are regulated by both CKs and glucose, nothing is known on the physiological relevance of the crosstalk between sugars and CKs in the control of root-lateral formation.

\subsection{Shoot Branching}

Shoot branching is a strictly regulated process that involves a very finely tuned hormonal and nutrient regulatory network [162-165] and is highly governed by environmental inputs [166]. In this intricate process, sugars and CKs behave as inducers, while auxin and strigolactones (SLs) act as repressors. However, whether sugars and CKs act synergistically or independently in this process remains unknown (Figure 5). Auxin derived from the young growing leaves of the apical meristem is transported down the stem through a specific polar auxin transport (PAT) stream and indirectly inhibits bud outgrowth through the opposite action of CKs and SLs [162,167]. The inducer effect of CKs has long been known [168]. This effect could occur through (i) the downregulation of the main inhibitor of shoot branching, Teosinte Branched 1/Branched1 (TB1/BRC1), within the bud [165], (ii) the stimulation of the sink strength of the buds for sugars $[169,170]$, and/or (iii) the promotion of auxin export from axillary buds to the main stem [171]. This latter mechanism is considered as a prerequisite for bud outgrowth in Arabidopsis and relies on the downregulation of a CK-signaling transcription factor (ARR1) and the upregulation of three auxin efflux carriers (PIN3, 4 and 7) [171-174]. PIN3/4/7 contributes to the local auxin transport between the PAT stream and surrounding tissues, referred to as connective auxin transport (CAT) [174]. The role of sugars in bud outgrowth is at the core of the historical nutrient diversion theory, which states that bud outgrowth is restricted by competition for the carbon resource in favor of the faster growing apical zone $[175,176]$. In addition, sugar starvation of the buds is tightly correlated to their dormancy status $[163,177]$. Sugars act as signaling molecules, as supported by their ability to downregulate $B R C 1[165,178]$ and by the fact that nonmetabolizable sugar analogs promote bud outgrowth in rose and pea [178-180]. Positive systemic signaling associated with sugar has been reported for etiolated stem branching in potato [181]. The T6P signaling pathway takes part in the local and systemic sugar-dependent regulation of bud outgrowth in Arabidopsis and in pea [182,183]. All these findings indicate that sugar mediates bud outgrowth through different sugar-signaling pathways, and additional investigations are needed to understand how they drive bud outgrowth individually and/or collectively. 


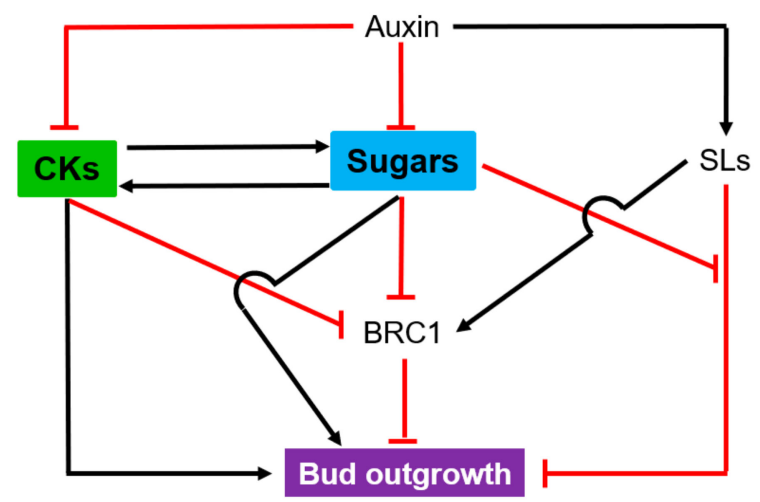

Figure 5. Synergistic effect of sugars and cytokinins (CKs) on bud outgrowth. Black arrows and red lines indicate stimulatory and inhibitory effects, respectively. SLs: strigolactones; BRC1: Branched1.

Current evidence shows crosstalk between sugars and SLs in rose, pea and rice $[5,184]$. In contrast, the basic regulatory mechanisms related to the sugar/CK interplay in the driving of shoot branching is still unknown. Sugars stimulated CK synthesis in one-node cuttings in vitro [178], and CKs could promote the expression of genes associated with the sink strength of buds for sugars [185]. Additional investigations are obviously required to elucidate how sugars and CKs synergistically regulate bud outgrowth. BRC1, which is under the control of sugars and CKs, could be an interesting hub for this regulation (Figure 5) [165].

\section{Leaf Senescence}

Leaf senescence can be a constitutive process of age-related development or an inducible mechanism triggered by unfavorable environmental conditions [186]. During this process, leaf cellular constituents and metabolites are actively recycled and exported to sink organs $[22,187,188]$. Leaf senescence is driven by sugars and hormones $[22,87,187,189,190]$. While acting cooperatively in growing leaves, sugars and CKs take on opposite roles in senescing leaves. Sugars promote the appearance of senescence symptoms [191,192]. Glucose highly promotes the expression of PAP1 and PAP2, two senescence-associated MYB transcription factor genes, and of the senescence-specific gene SAG12 [193]. This sugar-dependent induction of senescence could involve different sugar-related signaling pathways that may work in opposite manners. The best-characterized one is the HXKdependent signaling pathway: tomato or Arabidopsis HXK-overexpressing mutants exhibit high sensitivity to glucose and an accelerated senescence phenotype [194,195], while delayed senescence occurs in HXK knockout mutants [196,197]. Either increased T6P levels or reduced AtTOR activity triggers leaf senescence [198,199].

By contrast, CKs delay leaf senescence, as evidenced by results from exogenous supply of CKs, engineered plants with enhanced endogenous CK concentrations, and mutants deficient in CK signaling [200-203]. However, elevated expression of IPTs or LOG7a, two CK-encoding genes, has been unexpectedly reported in detached senescing leaves $[43,204,205]$. Delayed CK-mediated senescence is dependent on the activity of cell wall invertases (CWI) [206]. The tomato mutant deficient in INVINH1, an inhibitor of CWI activity- accordingly exhibited low leaf senescence [207]. The role of CWI in retarding leaf senescence is still unclear and may be more related to sugar signaling than to $C$ nutrient provision [208]. CKs could be involved in the regulation of the progression of leaf senescence by ensuring multiple roles, including scavengers of reactive oxygen species (ROS) or the maintenance of mitochondrial integrity $[188,201]$. Silencing the expression of RhPR10.1 (pathogenesis-related PR-10) in rose both accelerated flower senescence reduced $C K$ levels and downregulated three CK signaling pathway genes- $R h R R 3, R h R R 8$ and RhRR9 [209]. Additional key components of the CK signaling pathways, including a CK receptor (AHK3), a CK-response factor (CRF6), the type-B response regulator (ARR2) and 
the CRF-related AP2/ERF transcription factor family, also take part in the senescenceretarding role of CKs $[19,210,211]$.

Although sugars and CKs clearly have opposite effects on leaf senescence, the basic mechanism behind this crosstalk is still mostly unclear. One potential node may be the photosynthetic activity that influences the initiation of leaf senescence [212,213]. Photosynthetic activity is promoted by CKs [214] and repressed by sucrose and other derivative sugars accumulation through HXK-dependent signaling [215,216]. This mechanism involves Abscisic Acid Insensitive4 (ABI4), which encodes an ABA-regulated AP2 domain transcription factor [78]. Involved in the CK-dependent regulation of lateral root development [217], ABI4 may be an integrator of the antagonistic control of leaf senescence by sugars and CKs. Alternatively, a double mutant overexpressing IPT and HXK also showed early senescence-related characteristics comparatively to the IPT-overexpressing mutant and the WT, indicating a dominant role of sugars in the establishment of leaf senescence [218]. This is consistent with the presence of a set of sugar-signal-related motifs (e.g., YBGAHV, TATCCAOSAMY and ACGTABBOX) in the Glycine max promoter region of the IPT gene [219]. Future lines of research could target the way IP and root-derived CKs operate to antagonize the inductive effect of sugars on leaf senescence.

\section{Flowering}

Flowering is an important developmental process that ensures plant survival. The transition from the vegetative to the flowering stage must occur in a timely manner to maximize reproductive success. This developmental juvenile-to-adult reproductive switch is controlled by six major regulatory pathways that integrate different environmental and endogenous signals: the photoperiod, vernalization, gibberellins, ambient temperature, autonomous, and age [220]. This flowering network converges toward the major floral integrator gene FLOWERING LOCUS T (FT), its closest homolog TWIN SISTER OF FT (TSF), Suppressor of Overexpression of Constans 1 (SOC1), and FLOWERING LOCUS D (Figure 6) [220-222]. In Arabidopsis, a facultative long-day plant, sucrose concentrations in leaf exudates increase in response to inductive long days [223]. These increases in sucrose export levels result from carbohydrate mobilization rather than increased photosynthesis [224]. In line with this, sucrose supply can promote flowering in Arabidopsis and tomato $[225,226]$. However, high sucrose concentrations can have an inhibitory effect on floral transition [227]. Besides sucrose, glucose plays a major role in this process through the miR156/SPLs regulatory module identified as a key component of the aging pathway (Figure 6). Thus, the glucose-induced repression of miRNA156 is partly dependent on the signaling activity of HXK1 [228]. Sugar-mediated flower induction may also involve the signaling metabolite T6P, whose accumulation depends on T6P synthase 1 (TPS1) activity [229]. These authors showed that T6P pathway signaling in leaves is essential for both FT and TSF expression under inductive photoperiod. In addition, the T6P pathway also acts as a local signal in the SAM through the miRNA156-SPLs module independently of the photoperiod pathway. Transgenic Arabidopsis plants overexpressing jatropha T6P phosphatase (JcTPPJ) display a delayed flowering under inductive long days as compared to the WT [230]. Nevertheless, the Arabidopsis knockout mutant tppi exhibited the opposite phenotype, i.e., late-flowering under non-inductive conditions. This question means the regulation of flowering time by T6P, but also by downstream products of the T6P pathway like trehalose [231]. TSF inhibits the fructose phosphorylating activity of fructokinase 6 (FRK6) through direct interaction [232]. This potential regulatory role of the TSF-FRKs nexus in determining the flowering time of Arabidopsis is supported by the delayed flowering of the frk6 mutant under short-day conditions. In plants, CKs should be considered as an obligatory component of floral induction and may act both in leaves and shoot apices $[233,234]$. CK supply to Arabidopsis roots indeed promotes flowering and induces transcription of TSF in leaves as well as FD and SOC1 under short-day conditions independently of FT (Figure 6) [234]. Additionally, exogenous treatment with CKs could also induce SOC1 in the shoot meristem [233]. Gain-of-function variants of AHK2 and 
AHK3, two CK receptors, displayed enhanced CK signaling, resulting in early flowering under long-day conditions [235]. Consistent with these results, the rice $h k 5 h k 6$ mutant, disrupted for two HK cytokinin receptor genes, displayed severely delayed flowering [236]. SOC1, FD and ARR5-like were upregulated in sweet cherry tree buds during flowering induction when the highest amount of CKs was applied [237], as they were in apple tree buds when CKs were applied [11].

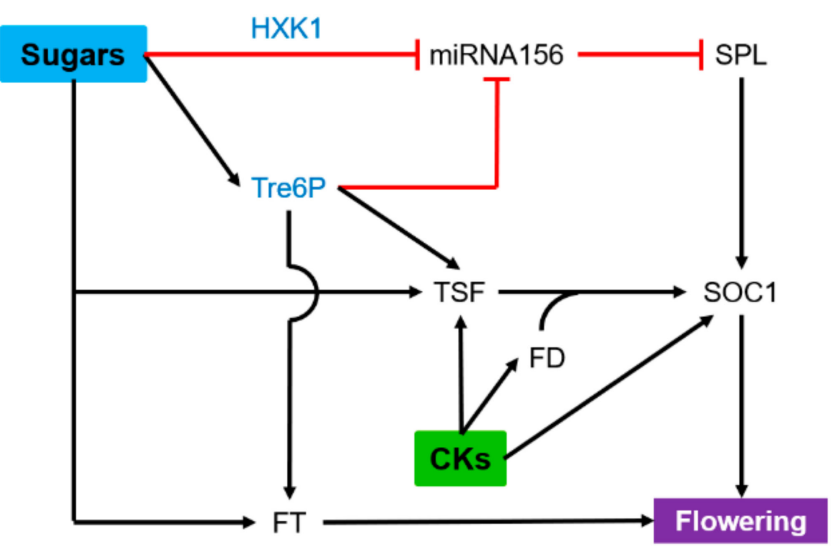

Figure 6. Synergistic effect of sugars and cytokinins (CKs) on flowering. Blue words indicate sugar signaling pathways. Black arrows and red lines indicate stimulatory and inhibitory effects, respectively. FD, FLOWERING LOCUS D; FT, FLOWERING LOCUS T; HXK1, hexokinase1; SOC1, Suppressor of Overexpression of Constans1; SPL, Squamosa Promoter-Binding Protein-Like; Tre6P: trehalose-6-phosphate; TSF, TWIN SISTER OF FT.

The role played by the crosstalk between sugars and CKs in the control of flowering is still almost unknown. Additional research is required to evaluate whether TSF, the paralog of FT, could be the main node of the combined effect of T6P and CKs.

\section{Conclusions}

Sugars and CKs play a pivotal role in morphogenesis and plant development because they are predominant during both the vegetative and reproductive stages of plant life (Figure 1). However, the detailed mechanism whereby these two regulators interplay is still puzzling, and many mechanistic scenarios are plausible. Many questions still remain open, include which molecular actors, which hubs could be involved at the crossroads of the sugar and CK signaling pathways. As the sugar/CK interplay can have antagonistic or agonistic outcomes, its regulatory network is expected to be complex and multifactorial depending on developmental and environmental inputs. Sugars and CKs both regulate the relationships between source and sink organs at the whole plant level. As a consequence, we may wonder about the relevance of the main energy and nutrient status sensors (Sucrose non-fermenting-related kinase (SnRK1)/target of rapamycin (TOR kinase)) in this process. The involvement of these mechanisms in this crosstalk deserves to be investigated. Meanwhile, our knowledge about the roles of sugars and CKs in the plant response to stressors is well investigated, but data about their crosstalk is again still very limited. Such an understanding is crucial to building up a comprehensive picture in different biological contexts throughout plant life. Further works are thus needed to fully investigate the regulatory networks behind the crosstalk between sugars and CKs. This will undoubtedly help to suitably manage plant physiology in view of increasing agronomy and resilience performances in an ever-changing environment. 
Author Contributions: All authors listed have made a direct contribution to the work and approved it for publication. M.W., J.L.G., P.G. and S.S. have designed the manuscript and written different parts of the manuscript. F.J., S.D.-M., M.-D.P.-G., L.O., L.H., L.C., J.C. and J.B. have contributed to the Section 3 "Meristem Establishment and Functioning" and Section 4 "Root and Shoot Branching". All authors have read and agreed to the published version of the manuscript.

Funding: This work was supported by the program of China Scholarships Council (No. 201506320203), Talent Introduction Special Funds of Qingdao Agricultural University (663/1120070) and by the ANR (Agence Nationale de la Recherche) project Labcom, called ESTIM (Evaluation de STIMulateurs de vitalité des plantes; Project ANR-15-LCV3-000).

Institutional Review Board Statement: Not applicable.

Informed Consent Statement: Not applicable.

Data Availability Statement: Not applicable.

Conflicts of Interest: The authors declare no conflict of interest.

\section{References}

1. Smeekens, S.; Ma, J.; Hanson, J.; Rolland, F. Sugar signals and molecular networks controlling plant growth. Curr. Opin. Plant Biol. 2010, 13, 273-278. [CrossRef] [PubMed]

2. Sakr, S.; Wang, M.; Dédaldéchamp, F.; Perez-Garcia, M.D.; Ogé, L.; Hamama, L.; Atanassova, R. The sugar-signaling hub: Overview of regulators and interaction with the hormonal and metabolic network. Int. J. Mol. Sci. 2018, 19, 2506. [CrossRef] [PubMed]

3. Wan, H.; Wu, L.; Yang, Y.; Zhou, G.; Ruan, Y.L. Evolution of sucrose metabolism: The dichotomy of invertases and beyond. Trends Plant Sci. 2018, 23, 163-177. [CrossRef] [PubMed]

4. Jiao, Y.; Lei, W.; Xu, W.; Chen, W.L. Glucose signaling, AtRGS1 and plant autophagy. Plant Signal. Behav. 2019, 14, 1607465. [CrossRef] [PubMed]

5. Wang, F.; Han, T.; Song, Q.; Ye, W.; Song, X.; Chu, J.; Li, J.; Chen, Z.J. The rice circadian clock regulates tiller growth and panicle development through strigolactone signaling and sugar sensing. Plant Cell 2020, 32, 3124-3138. [CrossRef]

6. Zhang, W.; Lunn, J.E.; Feil, R.; Wang, Y.; Zhao, J.; Tao, H.; Guo, Y.; Zhao, Z. Trehalose 6-phosphate signal is closely related to sorbitol in apple (Malus domesticaBorkh. cv. Gala). Biol. Open 2017, 6, 260-268. [CrossRef]

7. Demidchik, V.; Maathuis, F.; Voitsekhovskaja, O. Unravelling the plant signalling machinery: An update on the cellular and genetic basis of plant signal transduction. Funct. Plant Biol. 2018, 45, 1-8. [CrossRef]

8. Meng, D.; He, M.; Bai, Y.; Xu, H.; Dandekar, A.M.; Fei, Z.; Cheng, L. Decreased sorbitol synthesis leads to abnormal stamen development and reduced pollen tube growth via an MYB transcription factor, MdMYB39L, in apple (Malus domestica). New Phytologist. 2017, 217, 641-656. [CrossRef]

9. Kollist, H.; Zandalinas, S.I.; Sengupta, S.; Nuhkat, M.; Kangasjärvi, J.; Mittler, R. Rapid responses to abiotic stress: Priming the landscape for the signal transduction network. Trends Plant Sci. 2019, 24, 25-37. [CrossRef]

10. Chaput, V.; Martin, A.; Lejay, L. Redox metabolism: The hidden player in carbon and nitrogen signaling? J. Exp. Bot. 2020, 71, 3816-3826. [CrossRef]

11. Li, C.-L.; Meng, D.; Pineros, M.A.; MAO, Y.; Dandekar, A.M.; Cheng, L. A Sugar Transporter Takes Up both Hexose and Sucrose for Sorbitol-Modulated in vitro Pollen Tube Growth in Apple. Plant Cell 2020, 32, 449-469. [CrossRef] [PubMed]

12. Urano, D.; Miura, K.; Wu, Q.; Iwasaki, Y.; Jackson, D.; Jones, A.M. Plant morphology of heterotrimeric G protein mutants. Plant Cell Physiol. 2016, 57, 437-445. [CrossRef] [PubMed]

13. Stateczny, D.; Oppenheimer, J.; Bommert, P. G protein signaling in plants: Minus times minus equals plus. Curr. Opin. Plant Biol. 2016, 34, 127-135. [CrossRef] [PubMed]

14. Aguilera-Alvarado, G.P.; Sánchez-Nieto, S. Plant hexokinases are multifaceted proteins. Plant Cell Physiol. 2017, 58, 1151-1160. [CrossRef]

15. Ramon, M.; Dang, T.V.T.; Broeckx, T.; Hulsmans, S.; Crepin, N.; Sheen, J.; Rolland, F. Default activation and nuclear translocation of Plant Cellular energy sensor SnRK1 regulate metabolic stress responses and development. Plant Cell 2019, 31, 1614-1632. [CrossRef]

16. Margalha, L.; Confraria, A.; Baena-González, E. SnRK1 and TOR: Modulating growth-defense trade-offs in plant stress responses. J. Exp. Bot. 2019, 70, 2261-2274. [CrossRef]

17. Crepin, N.; Rolland, F. SnRK1 activation, signaling, and networking for energy homeostasis. Curr. Opin. Plant Biol. 2019, 51, 29-36. [CrossRef]

18. Quilichini, T.D.; Gao, P.; Pandey, P.K.; Xiang, D.; Ren, M.; Datla, R. A role for TOR signaling at every stage of plant life. J. Exp. Bot. 2019, 70, 2285-2296. [CrossRef] 
19. Raines, T.; Shanks, C.; Cheng, C.Y.; McPherson, D.; Argueso, C.T.; Kim, H.J.; Franco-Zorrilla, J.M.; López-Vidriero, I.; Solano, R.; Vaňková, R.; et al. The cytokinin response factors modulate root and shoot growth and promote leaf senescence in Arabidopsis. Plant J. 2016, 85, 134-147. [CrossRef]

20. Wang, G.; Zhang, G.; Wu, M. CLE peptide signaling and crosstalk with phytohormones and environmental stimuli. Front. Plant Sci. 2016, 6, 1211. [CrossRef]

21. Albrecht, T.; Argueso, C.T. Should I fight or should I grow now? The role of cytokinins in plant growth and immunity and in the growth-defence trade-off. Ann. Bot. 2017, 119, 725-735. [CrossRef] [PubMed]

22. Hönig, M.; Plíhalová, L.; Husičková, A.; Nisler, J.; Doležal, K. Role of cytokinins in senescence, antioxidant defence and photosynthesis. Int. J. Mol. Sci. 2018, 19, 4045. [CrossRef]

23. Kieber, J.J.; Schaller, G.E. Cytokinin signaling in plant development. Development 2018, 145, dev149344. [CrossRef]

24. Davière, J.M.; Achard, P. Organ communication: Cytokinins on the move. Nat. Plants 2017, 3, 1-2. [CrossRef]

25. Osugi, A.; Sakakibara, H. Q\&A: How do plants respond to cytokinins and what is their importance? BMC Biol. 2015, 13, 1-10.

26. Kurakawa, T.; Ueda, N.; Maekawa, M.; Kobayashi, K.; Kojima, M.; Nagato, Y.; Sakakibara, H.; Kyozuka, J. Direct control of shoot meristem activity by a cytokinin-activating enzyme. Nature 2007, 445, 652-655. [CrossRef] [PubMed]

27. Kuroha, T.; Tokunaga, H.; Kojima, M.; Ueda, N.; Ishida, T.; Nagawa, S.; Fukuda, H.; Sugimoto, K.; Sakakibara, H. Functional analyses of LONELY GUY cytokinin-activating enzymes reveal the importance of the direct activation pathway in Arabidopsis. Plant Cell 2009, 21, 3152-3169. [CrossRef] [PubMed]

28. Hwang, I.; Sheen, J.; Müller, B. Cytokinin signaling networks. Ann. Rev. Plant Biol. 2012, 63, 353-380. [CrossRef]

29. Osuna, D.; Prieto, P.; Aguilar, M. Control of seed germination and plant development by carbon and nitrogen availability. Front. Plant Sci. 2015, 6, 1023. [CrossRef]

30. Sami, F.; Siddiqui, H.; Hayat, S. Interaction of glucose and phytohormone signaling in plants. Plant Physiol. Biochem. 2019, 135, 119-126. [CrossRef]

31. Ohto, M.A.; Stone, S.L.; Harada, J.J. Genetic control of seed development and seed mass. Ann. Plant Rev. Online 2018, $27,1-24$.

32. Koch, K.E. Carbohydrate-modulated gene expression in plants. Ann. Rev. Plant Biol. 1996, 47, 509-540. [CrossRef] [PubMed]

33. Wobus, U.; Weber, H. Seed maturation: Genetic programmes and control signals. Curr. Opin. Plant Biol. 1999, 2, 33-38. [CrossRef]

34. Borisjuk, L.; Walenta, S.; Weber, H.; Mueller-Klieser, W.; Wobus, U. High-resolution histographical mapping of glucose concentrations in developing cotyledons of Vicia faba in relation to mitotic activity and storage processes: Glucose as a possible developmental trigger. Plant J. 1998, 15, 583-591. [CrossRef]

35. Weber, H.; Borisjuk, L.; Heim, U.; Buchner, P.; Wobus, P. Seed coat-associated invertases of fava bean control both unloading and storage functions: Cloning of cDNAs and cell type-specific expression. Plant Cell 1995, 7, 1835-1846. [PubMed]

36. Weber, H.; Borisjuk, L.; Heim, U.; Sauer, N.; Wobus, U. A role for sugar transporters during seed development: Molecular characterization of a hexose and a sucrose carrier in fava bean seeds. Plant Cell 1997, 9, 895-908. [CrossRef] [PubMed]

37. Rijavec, T.; Kovač, M.; Kladnik, A.; Chourey, P.S.; Dermastia, M. A comparative study on the role of cytokinins in caryopsis development in the maize miniature1 seed mutant and its wild type. J. Integr. Plant Biol. 2009, 51, 840-849. [CrossRef] [PubMed]

38. Rijavec, T.; Jain, M.; Dermastia, M.; Chourey, P.S. Spatial and temporal profiles of cytokinin biosynthesis and accumulation in developing caryopses of maize. Ann. Bot. 2011, 107, 1235-1245. [CrossRef]

39. Rijavec, T.; Li, Q.B.; Dermastia, M.; Chourey, P.S. Cytokinins and their possible role in seed size and seed mass determination in maize. Adv. Sel. Plant Physiol. Asp. 2012, 293.

40. Wang, L.; Ruan, Y.L. New insights into roles of cell wall invertase in early seed development revealed by comprehensive spatial and temporal expression patterns of GhCWIN1 in cotton. Plant Physiol. 2012, 160, 777-787. [CrossRef]

41. Ruan, Y.L.; Jin, Y.; Yang, Y.J.; Li, G.J.; Boyer, J.S. Sugar input, metabolism, and signaling mediated by invertase: Roles in development, yield potential, and response to drought and heat. Mol. Plant 2010, 3, 942-955. [CrossRef] [PubMed]

42. Riefler, M.; Novak, O.; Strnad, M.; Schmülling, T. Arabidopsis cytokinin receptor mutants reveal functions in shoot growth, leaf senescence, seed size, germination, root development, and cytokinin metabolism. Plant Cell 2006, 18, 40-54. [CrossRef] [PubMed]

43. Song, J.; Jiang, L.; Jameson, P.E. Expression patterns of Brassica napus genes implicate IPT, CKX, sucrose transporter, cell wall invertase and amino acid permease gene family members in leaf, flower, silique and seed development. J. Exp. Bot. 2015, 66, 5067-5082. [CrossRef] [PubMed]

44. Wang, L.; Ruan, Y.L. Regulation of cell division and expansion by sugar and auxin signaling. Front. Plant Sci. 2013, 4, 163. [CrossRef]

45. Wittich, P.E.; Vreugdenhil, D. Localization of sucrose synthase activity in developing maize kernels by in situ enzyme histochemistry. J. Exp. Bot. 1998, 49, 1163-1171. [CrossRef]

46. Perata, P.; Matsukura, C.; Vernieri, P.; Yamaguchi, J. Sugar repression of a gibberellin-dependent signaling pathway in barley embryos. Plant Cell 1997, 9, 2197-2208. [CrossRef]

47. Figueroa, C.M.; Lunn, J.E. A tale of two sugars: Trehalose 6-phosphate and sucrose. Plant Physiol. 2016, 172, 7-27. [CrossRef]

48. Baena-González, E.; Rolland, F.; Thevelein, J.M.; Sheen, J. A central integrator of transcription networks in plant stress and energy signalling. Nature 2007, 448, 938-942. [CrossRef]

49. Martínez-Barajas, E.; Delatte, T.; Schluepmann, H.; de Jong, G.J.; Somsen, G.W.; Nunes, C.; Primavesi, L.F.; Coello, P.; Mitchell, R.A.C.; Paul, M.J. Wheat grain development is characterized by remarkable trehalose 6-phosphate accumulation pregrain filling: Tissue distribution and relationship to SNF1-related protein kinase1 activity. Plant Physiol. 2011, 156, 373-381. [CrossRef] 
50. Griffiths, C.A.; Sagar, R.; Geng, Y.; Primavesi, L.F.; Patel, M.K.; Passarelli, M.K.; Gilmore, I.S.; Steven, R.T.; Bunch, J.; Paul, M.J.; et al. Chemical intervention in plant sugar signalling increases yield and resilience. Nature 2016, 540, 574-578. [CrossRef]

51. Eastmond, P.J.; Van Dijken, A.J.; Spielman, M.; Kerr, A.; Tissier, A.F.; Dickinson, H.G.; Jones, J.D.G.; Smeekens, S.C.; Graham, I.A. Trehalose-6-phosphate synthase 1, which catalyses the first step in trehalose synthesis, is essential for Arabidopsis embryo maturation. Plant J. 2002, 29, 225-235. [CrossRef] [PubMed]

52. Gómez, L.D.; Baud, S.; Gilday, A.; Li, Y.; Graham, I.A. Delayed embryo development in the ARABIDOPSIS TREHALOSE-6PHOSPHATE SYNTHASE 1 mutant is associated with altered cell wall structure, decreased cell division and starch accumulation. Plant J. 2006, 46, 69-84. [CrossRef] [PubMed]

53. Radchuk, R.; Radchuk, V.; Weschke, W.; Borisjuk, L.; Weber, H. Repressing the expression of the SUCROSE NONFERMENTING-1RELATED PROTEIN KINASE gene in pea embryo causes pleiotropic defects of maturation similar to an abscisic acid-insensitive phenotype. Plant Physiol. 2006, 140, 263-278. [CrossRef] [PubMed]

54. Radchuk, R.; Emery, R.N.; Weier, D.; Vigeolas, H.; Geigenberger, P.; Lunn, J.E.; Feil, R.; Weschke, W.; Weber, H. Sucrose nonfermenting kinase 1 (SnRK1) coordinates metabolic and hormonal signals during pea cotyledon growth and differentiation. Plant J. 2010, 61, 324-338. [CrossRef]

55. Tsai, A.Y.L.; Gazzarrini, S. AKIN10 and FUSCA3 interact to control lateral organ development and phase transitions in Arabidopsis. Plant J. 2012, 69, 809-821. [CrossRef] [PubMed]

56. Gazzarrini, S.; Tsai, A.Y.L. Trehalose-6-phosphate and SnRK1 kinases in plant development and signaling: The emerging picture. Front. Plant Sci. 2014, 5, 119.

57. Nambara, E.; Okamoto, M.; Tatematsu, K.; Yano, R.; Seo, M.; Kamiya, Y. Abscisic acid and the control of seed dormancy and germination. Seed Sci. Res. 2010, 20, 55. [CrossRef]

58. Tuan, P.A.; Kumar, R.; Rehal, P.K.; Toora, P.K.; Ayele, B.T. Molecular mechanisms underlying abscisic acid/gibberellin balance in the control of seed dormancy and germination in cereals. Front. Plant Sci. 2018, 9, 668. [CrossRef]

59. Tuan, P.A.; Yamasaki, Y.; Kanno, Y.; Seo, M.; Ayele, B.T. Transcriptomics of cytokinin and auxin metabolism and signaling genes during seed maturation in dormant and non-dormant wheat genotypes. Sci. Rep. 2019, 9, 1-16. [CrossRef]

60. Nonogaki, H.; Barrero, J.M.; Li, C. Seed dormancy, germination, and Pre-harvest sprouting. Front. Plant Sci. 2018, 9, 1783. [CrossRef]

61. Seo, M.; Nambara, E.; Choi, G.; Yamaguchi, S. Interaction of light and hormone signals in germinating seeds. Plant Mol. Biol. 2009, 69, 463-472. [CrossRef] [PubMed]

62. Finkelstein, R.R.; Lynch, T.J. The Arabidopsis abscisic acid response gene ABI5 encodes a basic leucine zipper transcription factor. Plant Cell 2000, 12, 599-609. [PubMed]

63. Ullah, H.; Chen, J.G.; Wang, S.; Jones, A.M. Role of a heterotrimeric G protein in regulation of Arabidopsis seed germination. Plant Physiol. 2002, 129, 897-907. [CrossRef] [PubMed]

64. Rolland, F.; Baena-Gonzalez, E.; Sheen, J. Sugar sensing and signaling in plants: Conserved and novel mechanisms. Ann. Rev. Plant Biol. 2006, 57, 675-709. [CrossRef] [PubMed]

65. Arenas-Huertero, F.; Arroyo, A.; Zhou, L.; Sheen, J.; León, P. Analysis of Arabidopsis glucose insensitive mutants, gin5 and gin6, reveals a central role of the plant hormone ABA in the regulation of plant vegetative development by sugar. Genes Dev. 2000, 14, 2085-2096. [PubMed]

66. Rolland, F.; Moore, B.; Sheen, J. Sugar sensing and signaling in plants. Plant Cell 2002, 14 (Suppl. 1), S185-S205. [CrossRef]

67. Price, J.; Li, T.C.; Kang, S.G.; Na, J.K.; Jang, J.C. Mechanisms of glucose signaling during germination of Arabidopsis. Plant Physiol. 2003, 132, 1424-1438. [CrossRef]

68. Gibson, S.I. Control of plant development and gene expression by sugar signaling. Curr. Opin. Plant Biol. 2005, 8, 93-102. [CrossRef]

69. Dekkers, B.J.; Schuurmans, J.A.; Smeekens, S.C. Glucose delays seed germination in Arabidopsis thaliana. Planta 2004, 218, 579-588. [CrossRef]

70. Chen, Y.; Ji, F.; Xie, H.; Liang, J.; Zhang, J. The regulator of G-protein signaling proteins involved in sugar and abscisic acid signaling in Arabidopsis seed germination. Plant Physiol. 2006, 140, 302-310. [CrossRef]

71. Urano, D.; Phan, N.; Jones, J.C.; Yang, J.; Huang, J.; Grigston, J.; Taylor, P.; Jones, A.M. Endocytosis of the seven-transmembrane RGS1 protein activates G-protein-coupled signalling in Arabidopsis. Nat. Cell Biol. 2012, 14, 1079-1088. [CrossRef] [PubMed]

72. Pandey, S.; Chen, J.G.; Jones, A.M.; Assmann, S.M. G-protein complex mutants are hypersensitive to abscisic acid regulation of germination and postgermination development. Plant Physiol. 2006, 141, 243-256. [CrossRef] [PubMed]

73. Zhong, C.; Xu, H.; Ye, S.; Wang, S.; Li, L.; Zhang, S.; Wang, X. AtGASA6 serves as an integrator of gibberellin-, abscisic acid-and glucose-signaling during seed germination in Arabidopsis. Plant Physiol. 2015, 169, 2288-2303. [CrossRef] [PubMed]

74. Qu, J.; Kang, S.G.; Hah, C.; Jang, J.C. Molecular and cellular characterization of GA-Stimulated Transcripts GASA4 and GASA6 in Arabidopsis thaliana. Plant Sci. 2016, 246, 1-10. [CrossRef] [PubMed]

75. Schluepmann, H.; Pellny, T.; van Dijken, A.; Smeekens, S.; Paul, M. Trehalose 6-phosphate is indispensable for carbohydrate utilization and growth in Arabidopsis thaliana. Proc. Natl. Acad. Sci. USA 2003, 100, 6849-6854. [CrossRef] [PubMed]

76. Avonce, N.; Leyman, B.; Mascorro-Gallardo, J.O.; Van Dijck, P.; Thevelein, J.M.; Iturriaga, G. The Arabidopsis trehalose-6-P synthase AtTPS1 gene is a regulator of glucose, abscisic acid, and stress signaling. Plant Physiol. 2004, 136, 3649-3659. [CrossRef] [PubMed] 
77. Vandesteene, L.; López-Galvis, L.; Vanneste, K.; Feil, R.; Maere, S.; Lammens, W.; Rolland, F.; Lunn, J.E.; Avonce, N.; Beeckman, T.; et al. Expansive evolution of the trehalose-6-phosphate phosphatase gene family in Arabidopsis. Plant Physiol. 2012, 160, 884-896. [CrossRef] [PubMed]

78. Shu, K.; Liu, X.D.; Xie, Q.; He, Z.H. Two faces of one seed: Hormonal regulation of dormancy and germination. Mol. Plant 2016, 9, 34-45. [CrossRef]

79. Khan, A.A. Cytokinins: Permissive role in seed germination. Science 1971, 171, 853-859. [CrossRef]

80. Jameson, P.E.; Dhandapani, P.; Novak, O.; Song, J. Cytokinins and expression of SWEET, SUT, CWINV and AAP genes increase as pea seeds germinate. Int. J. Mol. Sci. 2016, 17, 2013. [CrossRef]

81. Wang, Y.; Li, L.; Ye, T.; Zhao, S.; Liu, Z.; Feng, Y.Q.; Wu, Y. Cytokinin antagonizes ABA suppression to seed germination of Arabidopsis by downregulating ABI5 expression. Plant J. 2011, 68, 249-261. [CrossRef] [PubMed]

82. Guan, C.; Wang, X.; Feng, J.; Hong, S.; Liang, Y.; Ren, B.; Zuo, J. Cytokinin antagonizes abscisic acid-mediated inhibition of cotyledon greening by promoting the degradation of abscisic acid insensitive 5 protein in Arabidopsis. Plant Physiol. 2014, 164, 1515-1526. [CrossRef] [PubMed]

83. Cheng, W.H.; Endo, A.; Zhou, L.; Penney, J.; Chen, H.C.; Arroyo, A.; Leon, P.; Nambara, E.; Asami, T.; Seo, M.; et al. A unique short-chain dehydrogenase/reductase in Arabidopsis glucose signaling and abscisic acid biosynthesis and functions. Plant Cell 2002, 14, 2723-2743. [CrossRef] [PubMed]

84. Huang, X.; Zhang, X.; Gong, Z.; Yang, S.; Shi, Y. ABI4 represses the expression of type-A ARRs to inhibit seed germination in Arabidopsis. Plant J. 2017, 89, 354-365. [CrossRef]

85. Li, Y.; Li, L.L.; Fan, R.C.; Peng, C.C.; Sun, H.L.; Zhu, S.Y.; Wang, X.F.; Zhang, L.Y.; Zhang, D.P. Arabidopsis sucrose transporter SUT4 interacts with cytochrome b5-2 to regulate seed germination in response to sucrose and glucose. Mol. Plant 2012, 5, 1029-1041. [CrossRef]

86. Niemann, M.C.; Werner, T. Endoplasmic reticulum: Where nucleotide sugar transport meets cytokinin control mechanisms. Plant Signal. Behav. 2015, 10, e1072668. [CrossRef]

87. Swartzberg, D.; Hanael, R.; Granot, D. Relationship between hexokinase and cytokinin in the regulation of leaf senescence and seed germination. Plant Biol. 2011, 13, 439-444. [CrossRef]

88. Kircher, S.; Schopfer, P. Photosynthetic sucrose acts as cotyledon-derived long-distance signal to control root growth during early seedling development in Arabidopsis. Proc. Natl. Acad. Sci. USA 2012, 109, 11217-11221. [CrossRef]

89. Kushwah, S.; Laxmi, A. The interaction between glucose and cytokinin signaling in controlling Arabidopsis thaliana seedling root growth and development. Plant Signal. Behav. 2017, 12, e1312241. [CrossRef]

90. Kushwah, S.; Laxmi, A. The interaction between glucose and cytokinin signal transduction pathway in Arabidopsis thaliana. Plant Cell Environ. 2014, 37, 235-253. [CrossRef]

91. Tsai, Y.C.; Weir, N.R.; Hill, K.; Zhang, W.; Kim, H.J.; Shiu, S.H.; Schaller, G.E.; Kieber, J.J. Characterization of genes involved in cytokinin signaling and metabolism from rice. Plant Physiol. 2012, 158, 1666-1684. [CrossRef] [PubMed]

92. Gómez, L.D.; Gilday, A.; Feil, R.; Lunn, J.E.; Graham, I.A. AtTPS1-mediated trehalose 6-phosphate synthesis is essential for embryogenic and vegetative growth and responsiveness to ABA in germinating seeds and stomatal guard cells. Plant J. 2010, 64, 1-13. [CrossRef]

93. Huang, X.; Hou, L.; Meng, J.; You, H.; Li, Z.; Gong, Z.; Yang, S.; Shi, Y. The antagonistic action of abscisic acid and cytokinin signaling mediates drought stress response in Arabidopsis. Mol. Plant 2018, 11, 970-982. [CrossRef] [PubMed]

94. Peng, L.; Skylar, A.; Chang, P.L.; Bisova, K.; Wu, X. CYCP2; 1 integrates genetic and nutritional information to promote meristem cell division in Arabidopsis. Dev. Biol. 2014, 393, 160-170. [CrossRef]

95. Cai, W.; Li, X.; Liu, Y.; Wang, Y.; Zhou, Y.; Xu, T.; Xiong, Y. COP1 integrates light signals to ROP2 for cell cycle activation. Plant Signal. Behav. 2017, 12, e1363946. [CrossRef] [PubMed]

96. Díaz-Granados, V.H.; López-López, J.M.; Flores-Sánchez, J.; Olguin-Alor, R.; Bedoya-López, A.; Dinkova, T.D.; Salazar-Díaza, K.; Vázquez-Santana, S.; Vázquez-Ramosa, J.M.; Lara-Núñeza, A. Glucose modulates proliferation in root apical meristems via TOR in maize during germination. Plant Physiol. Biochem. 2020, 155, 126-135. [CrossRef] [PubMed]

97. Qi, F.; Zhang, F. Cell Cycle Regulation in the Plant Response to Stress. Front. Plant Sci. 2020, 10, 1765. [CrossRef]

98. Wang, J.; Tian, C.; Zhang, C.; Shi, B.; Cao, X.; Zhang, T.Q.; Zhao, Z.; Wang, J.; Jiao, Y. Cytokinin signaling activates WUSCHEL expression during axillary meristem initiation. Plant Cell 2017, 29, 1373-1387. [CrossRef]

99. Wybouw, B.; De Rybel, B. Cytokinin-a developing story. Trends Plant Sci. 2019, 24, 177-185. [CrossRef]

100. Olatunji, D.; Geelen, D.; Verstraeten, I. Control of endogenous auxin levels in plant root development. Int. J. Mol. Sci. 2017, 18, 2587. [CrossRef]

101. Huang, L.; Yu, L.J.; Zhang, X.; Fan, B.; Wang, F.Z.; Dai, Y.S.; Xiao, S. Autophagy regulates glucose-mediated root meristem activity by modulating ROS production in Arabidopsis. Autophagy 2019, 15, 407-422. [CrossRef] [PubMed]

102. Yuan, T.T.; Xu, H.H.; Zhang, K.X.; Guo, T.T.; Lu, Y.T. Glucose inhibits root meristem growth via ABA INSENSITIVE 5, which represses PIN1 accumulation and auxin activity in Arabidopsis. Plant Cell Environ. 2014, 37, 1338-1350. [CrossRef] [PubMed]

103. Destefano-Beltrán, L.; Knauber, D.; Huckle, L.; Suttle, J. Chemically forced dormancy termination mimics natural dormancy progression in potato tuber meristems by reducing ABA content and modifying expression of genes involved in regulating ABA synthesis and metabolism. J. Exp. Bot. 2006, 57, 2879-2886. [CrossRef] [PubMed] 
104. Jossier, M.; Bouly, J.P.; Meimoun, P.; Arjmand, A.; Lessard, P.; Hawley, S.; Hardie, D.G.; Thomas, M. SnRK1 (SNF1-related kinase 1) has a central role in sugar and ABA signalling in Arabidopsis thaliana. Plant J. 2009, 59, 316-328. [CrossRef] [PubMed]

105. Zhang, H.; Han, W.; De Smet, I.; Talboys, P.; Loya, R.; Hassan, A.; Rong, H.; Jürgens, G.; Knox, J.P.; Wang, M.H. ABA promotes quiescence of the quiescent centre and suppresses stem cell differentiation in the Arabidopsis primary root meristem. Plant $J$. 2010, 64, 764-774. [CrossRef]

106. Tsugama, D.; Liu, S.; Takano, T. A putative myristoylated 2C-type protein phosphatase, PP2C74, interacts with SnRK1 in Arabidopsis. Febs Lett. 2012, 586, 693-698. [CrossRef]

107. Emanuelle, S.; Doblin, M.S.; Stapleton, D.I.; Bacic, A.; Gooley, P.R. Molecular insights into the enigmatic metabolic regulator, SnRK1. Trends Plant Sci. 2016, 21, 341-353. [CrossRef]

108. Soto-Burgos, J.; Bassham, D.C. SnRK1 activates autophagy via the TOR signaling pathway in Arabidopsis thaliana. PLoS ONE 2017, e0182591. [CrossRef]

109. Arroyo, A.; Bossi, F.; Finkelstein, R.R.; León, P. Three genes that affect sugar sensing (abscisic acid insensitive 4, abscisic acid insensitive 5, and constitutive triple response 1) are differentially regulated by glucose in Arabidopsis. Plant Physiol. 2003, 133, 231-242. [CrossRef]

110. Skubacz, A.; Daszkowska-Golec, A.; Szarejko, I. The role and regulation of ABI5 (ABA-Insensitive 5) in plant development, abiotic stress responses and phytohormone crosstalk. Front. Plant Sci. 2016, 7, 1884. [CrossRef]

111. Baena-González, E.; Hanson, J. Shaping plant development through the SnRK1-TOR metabolic regulators. Curr. Opin. Plant Biol. 2017, 35, 152-157. [CrossRef] [PubMed]

112. Pu, Y.; Soto-Burgos, J.; Bassham, D.C. Regulation of autophagy through SnRK1 and TOR signaling pathways. Plant Signal. Behav. 2017, 12, 1204. [CrossRef] [PubMed]

113. Fu, L.; Wang, P.; Xiong, Y. Target of Rapamycin Signaling in Plant Stress Responses. Plant Physiol. 2020, 182, 1613-1623. [CrossRef] [PubMed]

114. Xiong, Y.; Sheen, J. Novel links in the plant TOR kinase signaling network. Curr. Opin. Plant Biol. 2015, 28, 83-91. [CrossRef] [PubMed]

115. Xiong, Y.; McCormack, M.; Li, L.; Hall, Q.; Xiang, C.; Sheen, J. Glucose-TOR signalling reprograms the transcriptome and activates meristems. Nature 2013,496, 181. [CrossRef]

116. Lu, B.; Wen, S.; Zhu, P.; Cao, H.; Zhou, Y.; Bie, Z.; Cheng, J. Overexpression of melon tonoplast sugar transporter CmTST1 improved root growth under high sugar content. Int. J. Mol. Sci. 2020, 21, 3524. [CrossRef]

117. Barrada, A.; Djendli, M.; Desnos, T.; Mercier, R.; Robaglia, C.; Montané, M.H.; Menand, B. A TOR-YAK1 signaling axis controls cell cycle, meristem activity and plant growth in Arabidopsis. Development 2019, 146, dev171298. [CrossRef]

118. Kyozuka, J. Control of shoot and root meristem function by cytokinin. Curr. Opin. Plant Biol. 2007, 10, 442-446. [CrossRef]

119. Gordon, S.P.; Chickarmane, V.S.; Ohno, C.; Meyerowitz, E.M. Multiple feedback loops through cytokinin signaling control stem cell number within the Arabidopsis shoot meristem. Proc. Natl. Acad. Sci. USA 2009, 106, 16529-16534. [CrossRef]

120. Poza-Viejo, L.; Abreu, I.; González-García, M.P.; Allauca, P.; Bonilla, I.; Bolaños, L.; Reguera, M. Boron deficiency inhibits root growth by controlling meristem activity under cytokinin regulation. Plant Sci. 2018, 270, 176-189. [CrossRef]

121. Ivanov, V.B.; Filin, A.N. Cytokinins regulate root growth through its action on meristematic cell proliferation but not on the transition to differentiation. Funct. Plant Biol. 2018, 45, 215-221. [CrossRef] [PubMed]

122. Higuchi, M.; Pischke, M.S.; Mähönen, A.P.; Miyawaki, K.; Hashimoto, Y.; Seki, M.; Kobayashi, M.; Shinozaki, K.; Kato, T.; Tabata, S.; et al. In planta functions of the Arabidopsis cytokinin receptor family. Proc. Natl. Acad. Sci. USA 2004, 101, 8821-8826. [CrossRef] [PubMed]

123. Nishimura, C.; Ohashi, Y.; Sato, S.; Kato, T.; Tabata, S.; Ueguchi, C. Histidine kinase homologs that act as cytokinin receptors possess overlapping functions in the regulation of shoot and root growth in Arabidopsis. Plant Cell 2004, 16, 1365-1377. [CrossRef] [PubMed]

124. Ioio, R.D.; Linhares, F.S.; Scacchi, E.; Casamitjana-Martinez, E.; Heidstra, R.; Costantino, P.; Sabatini, S. Cytokinins determine Arabidopsis root-meristem size by controlling cell differentiation. Curr. Biol. 2007, 17, 678-682. [CrossRef] [PubMed]

125. Doerner, P. Plant Meristems: Cytokinins-the alpha and omega of the meristem. Curr. Biol. 2007, 17, R321-R323. [CrossRef] [PubMed]

126. Barrera-Rojas, C.H.; Rocha, G.H.B.; Polverari, L.; Pinheiro Brito, D.A.; Batista, D.S.; Notini, M.M.; Ferreira da Cruz, A.C.; Morea, E.G.O.; Sabatini, S.; Otoni, W.C.; et al. miR156-targeted SPL10 controls Arabidopsis root meristem activity and root-derived de novo shoot regeneration via cytokinin responses. J. Exp. Bot. 2020, 71, 934-950. [CrossRef]

127. Ponnu, J.; Schlereth, A.; Zacharaki, V.; Działo, M.A.; Abel, C.; Feil, R.; Schmid, M.; Wahl, V. The trehalose 6-phosphate pathway impacts vegetative phase change in Arabidopsis thaliana. Plant J. 2020, 104, 768-780. [CrossRef]

128. Li, T.; Kang, X.; Lei, W.; Yao, X.; Zou, L.; Zhang, D.; Lin, H. SHY2 as a node in the regulation of root meristem development by auxin, brassinosteroids, and cytokinin. J. Integr. Plant Biol. 2020, 62, 1500-1517. [CrossRef]

129. Hallmark, H.T.; Rashotte, A.M. Review-Cytokinin Response Factors: Responding to more than cytokinin. Plant Sci. 2019, 289, 110251. [CrossRef]

130. Moore, B.; Zhou, L.; Rolland, F.; Hall, Q.; Cheng, W.H.; Liu, Y.X.; Hwang, I.; Jones, T.; Sheen, J. Role of the Arabidopsis glucose sensor HXK1 in nutrient, light, and hormonal signaling. Science 2003, 300, 332-336. [CrossRef] 
131. Paul, M.J.; Primavesi, L.F.; Jhurreea, D.; Zhang, Y. Trehalose metabolism and signaling. Ann. Rev. Plant Biol. $2008,59,417-441$. [CrossRef] [PubMed]

132. Skylar, A.; Sung, F.; Hong, F.; Chory, J.; Wu, X. Metabolic sugar signal promotes Arabidopsis meristematic proliferation via G2. Dev. Biol. 2011, 351, 82-89.

133. Li, X.; Cai, W.; Liu, Y.; Li, H.; Fu, L.; Liu, Z.; Xu, L.; Liu, H.; Xu, T.; Xiong, Y. Differential TOR activation and cell proliferation in Arabidopsis root and shoot apexes. Proc. Natl. Acad. Sci. USA 2017, 114, 2765-2770. [CrossRef] [PubMed]

134. Fragoso, S.; Espindola, L.; Paez-Valencia, J.; Gamboa, A.; Camacho, Y.; Martinez-Barajas, E.; Coello, P. SnRK1 isoforms akin10 and akin11 are differentially regulated in Arabidopsis plants under phosphate starvation. Plant Physiol. 2009, 149, $1906-1916$. [CrossRef]

135. Zürcher, E.; Liu, J.; di Donato, M.; Geisler, M.; Müller, B. Plant development regulated by cytokinin sinks. Science 2016, 353, 1027-1030. [CrossRef]

136. Landrein, B.; Formosa-Jordan, P.; Malivert, A.; Schuster, C.; Melnyk, C.W.; Yang, W.; Turnbull, C.; Meyerowitz, E.M.; Locke, J.C.W.; Jönsson, H. Nitrate modulates stem cell dynamics in Arabidopsis shoot meristems through cytokinins. Proc. Natl. Acad. Sci. USA 2018, 115, 1382-1387. [CrossRef]

137. Schoof, H.; Lenhard, M.; Haecker, A.; Mayer, K.F.; Jürgens, G.; Laux, T. The stem cell population of Arabidopsis shoot meristems is maintained by a regulatory loop between the CLAVATA and WUSCHEL genes. Cell 2000, 100, 635-644. [CrossRef]

138. Lenhard, M.; Jürgens, G.; Laux, T. The WUSCHEL and SHOOTMERISTEMLESS genes fulfil complementary roles in Arabidopsis shoot meristem regulation. Development 2002, 129, 3195-3206.

139. Xin, W.; Wang, Z.; Liang, Y.; Wang, Y.; Hu, Y. Dynamic expression reveals a two-step patterning of WUS and CLV3 during axillary shoot meristem formation in Arabidopsis. J. Plant Physiol. 2017, 214, 1-6. [CrossRef]

140. To, J.P.; Haberer, G.; Ferreira, F.J.; Deruere, J.; Mason, M.G.; Schaller, G.E.; Alonso, J.M.; Ecker, J.R.; Kieber, J.J. Type-A Arabidopsis response regulators are partially redundant negative regulators of cytokinin signaling. Plant Cell 2004, 16, 658-671. [CrossRef]

141. Leibfried, A.; To, J.P.; Busch, W.; Stehling, S.; Kehle, A.; Demar, M.; Lohmann, J.U. WUSCHEL controls meristem function by direct regulation of cytokinin-inducible response regulators. Nature 2005, 438, 1172. [CrossRef] [PubMed]

142. Wu, X.; Dabi, T.; Weigel, D. Requirement of homeobox gene STIMPY/WOX9 for Arabidopsis meristem growth and maintenance. Curr. Biol. 2005, 15, 436-440. [CrossRef] [PubMed]

143. Skylar, A.; Hong, F.; Chory, J.; Weigel, D.; Wu, X. STIMPY mediates cytokinin signaling during shoot meristem establishment in Arabidopsis seedlings. Development 2010, 137, 541-549. [CrossRef] [PubMed]

144. Bartrina, I.; Otto, E.; Strnad, M.; Werner, T.; Schmulling, T. Cytokinin regulates the activity of reproductive meristems, flower organ size, ovule formation, and thus seed yield in arabidopsis thaliana. Plant Cell 2011, 23, 69-80. [CrossRef]

145. de Vries, J.; Fischer, A.M.; Roettger, M.; Rommel, S.; Schluepmann, H.; Bräutigam, A.; Carlsbecker, A.; Gould, S.B. Cytokinininduced promotion of root meristem size in the fern Azolla supports a shoot-like origin of euphyllophyte roots. New Phytol. 2016, 209, 705-720. [CrossRef]

146. Kong, D.; Hao, Y.; Cui, H. The WUSCHEL related homeobox protein WOX7 regulates the sugar response of lateral root development in Arabidopsis thaliana. Mol. Plant 2016, 9, 261-270. [CrossRef]

147. Du, Y.; Scheres, B. Lateral root formation and the multiple roles of auxin. J. Exp. Bot. 2018, 69, 155-167. [CrossRef]

148. Hammond, J.P.; White, P.J. Sugar signaling in root responses to low phosphorus availability. Plant Physiol. 2011, 156, 1033-1040. [CrossRef]

149. Booker, K.S.; Schwarz, J.; Garrett, M.B.; Jones, A.M. Glucose attenuation of auxin-mediated bimodality in lateral root formation is partly coupled by the heterotrimeric G protein complex. PLoS ONE 2010, 5, e12833. [CrossRef]

150. Qi, X.; Wu, Z.; Li, J.; Mo, X.; Wu, S.; Chu, J.; Wu, P. AtCYT-INV1, a neutral invertase, is involved in osmotic stress-induced inhibition on lateral root growth in Arabidopsis. Plant Mol. Biol. 2007, 64, 575-587. [CrossRef]

151. Kiba, T.; Takebayashi, Y.; Kojima, M.; Sakakibara, H. Sugar-induced de novo cytokinin biosynthesis contributes to Arabidopsis growth under elevated CO. Sci. Rep. 2019, 9, 1-15. [CrossRef] [PubMed]

152. Chapman, K.; Taleski, M.; Ogilvie, H.A.; Imin, N.; Djordjevic, M.A. CEP-CEPR1 signalling inhibits the sucrose-dependent enhancement of lateral root growth. J. Exp. Bot. 2019, 70, 3955-3967. [CrossRef] [PubMed]

153. Konieczny, R.; Kępczyński, J.; Pilarska, M.; Cembrowska, D.; Menzel, D.; Šamaj, J. Cytokinin and ethylene affect auxin transportdependent rhizogenesis in hypocotyls of common ice plant (Mesembryanthemum crystallinum L.). J. Plant Growth Regul. 2009, 28, 331. [CrossRef]

154. Laplaze, L.; Benkova, E.; Casimiro, I.; Maes, L.; Vanneste, S.; Swarup, R.; Weijers, D.; Calvo, V.; Parizot, B.; Herrera-Rodriguez, M.B.; et al. Cytokinins act directly on lateral root founder cells to inhibit root initiation. Plant Cell 2007, 19, 3889-3900. [CrossRef] [PubMed]

155. Davis, L.O.M.M.; Ogita, N.; Inagaki, S.; Takahashi, N.; Umeda, M. DNA damage inhibits lateral root formation by up-regulating cytokinin biosynthesis genes in Arabidopsis thaliana. Genes Cells 2016, 21, 1195-1208. [CrossRef]

156. Li, X.; Mo, X.; Shou, H.; Wu, P. Cytokinin-mediated cell cycling arrest of pericycle founder cells in lateral root initiation of Arabidopsis. Plant Cell Physiol. 2006, 47, 1112-1123. [CrossRef]

157. Jing, H.; Strader, L.C. Interplay of auxin and cytokinin in lateral root development. Int. J. Mol. Sci. 2019, 20, 486. [CrossRef]

158. Márquez, G.; Alarcón, M.V.; Salguero, J. Cytokinin Inhibits Lateral Root Development at the Earliest Stages of Lateral Root Primordium Initiation in Maize Primary Root. J. Plant Growth Regul. 2019, 38, 83-92. [CrossRef] 
159. Jeon, J.; Cho, C.; Lee, M.R.; Van Binh, N.; Kim, J. CYTOKININ RESPONSE FACTOR2 (CRF2) and CRF3 regulate lateral root development in response to cold stress in Arabidopsis. Plant Cell 2016, 28, 1828-1843. [CrossRef]

160. Chang, L.; Ramireddy, E.; Schmülling, T. Cytokinin as a positional cue regulating lateral root spacing in Arabidopsis. J. Exp. Bot. 2015, 66, 4759-4768. [CrossRef]

161. Li, G.; Ma, J.; Tan, M.; Mao, J.; An, N.; Sha, G.; Zhang, D.; Zhao, C.; Han, M. Transcriptome analysis reveals the effects of sugar metabolism and auxin and cytokinin signaling pathways on root growth and development of grafted apple. BMC Genom. 2016, 17, 150. [CrossRef] [PubMed]

162. Rameau, C.; Bertheloot, J.; Leduc, N.; Andrieu, B.; Foucher, F.; Sakr, S. Multiple pathways regulate shoot branching. Front. Plant Sci. 2015, 5, 741. [CrossRef] [PubMed]

163. Martin-Fontecha, E.S.; Tarancan, C.; Cubas, P. To grow or not to grow, a power-saving program induced in dormant buds. Curr. Opin. Plant Biol. 2017, 41, 102-109. [CrossRef] [PubMed]

164. Barbier, F.F.; Dun, E.A.; Kerr, S.C.; Chabikwa, T.G.; Beveridge, C.A. An update on the signals controlling shoot branching. Trends Plant Sci. 2019, 24, 220-236. [CrossRef]

165. Wang, M.; Le Moigne, M.A.; Bertheloot, J.; Crespel, L.; Perez-Garcia, M.D.; Ogé, L.; Demotes-Mainard, S.; Hamama, L.; Davière, J.M.; Sakr, S. BRANCHED1: A key hub of shoot branching. Front. Plant Sci. 2019, 10, 76. [CrossRef]

166. Schneider, A.; Godin, C.; Boudon, F.; Demotes-Mainard, S.; Sakr, S.; Bertheloot, J. Light regulation of axillary bud outgrowth along plant axes: An overview of the roles of sugars and hormones. Front. Plant Sci. 2019, 10, 1296. [CrossRef]

167. Domagalska, M.A.; Leyser, O. Signal integration in the control of shoot branching. Nat. Rev. Mol. Cell Biol. 2011, 12, 211-221. [CrossRef]

168. Müller, D.; Leyser, O. Auxin, cytokinin and the control of shoot branching. Ann. Bot. 2011, 107, 1203-1212. [CrossRef]

169. Buskila, Y.; Sela, N.; Teper-Bamnolker, P.; Tal, I.; Shani, E.; Weinstain, R.; Gaba, V.; Tam, Y.; Lers, A.; Eshel, D. Stronger sink demand for metabolites supports dominance of the apical bud in etiolated growth. J. Exp. Bot. 2016, 67, 5495-5508. [CrossRef]

170. Henry, C.; Rabot, A.; Laloi, M.; Mortreau, E.; Sigogne, M.; Leduc, N.; Lemoine, R.; Sakr, S.; Vian, A.; Pelleschi-Travier, S. Regulation of RhSUC2, a sucrose transporter, is correlated with the light control of bud burst in Rosa sp. Plant Cell Environ. 2011, 34, 1776-1789. [CrossRef]

171. Waldie, T.; Leyser, O. Cytokinin targets auxin transport to promote shoot branching. Plant Physiol. 2018, 177, 803-818. [CrossRef] [PubMed]

172. Balla, J.; Kalousek, P.; Reinöhl, V.; Friml, J.; Procházka, S. Competitive canalization of PIN-dependent auxin flow from axillary buds controls pea bud outgrowth. Plant J. 2011, 65, 571-577. [CrossRef] [PubMed]

173. Balla, J.; Medved'ová, Z.; Kalousek, P.; Matiješčuková, N.; Friml, J.; Reinöhl, V.; Procházka, S. Auxin flow-mediated competition between axillary buds to restore apical dominance. Sci. Rep. 2016, 6, 35955. [CrossRef] [PubMed]

174. Van Rongen, M.; Bennett, T.; Ticchiarelli, F.; Leyser, O. Connective auxin transport contributes to strigolactone-mediated shoot branching control independent of the transcription factor BRC. PloS Genet. 2019, 15, e1008023. [CrossRef]

175. Hall, S.M.; Hillman, J.R. Correlative inhibition of lateral bud growth in Phaseolus vulgaris L. Timing of bud growth following decapitation. Planta 1975, 123, 137-143. [CrossRef]

176. Mason, M.G.; Ross, J.J.; Babst, B.A.; Wienclaw, B.N.; Beveridge, C.A. Sugar demand, not auxin, is the initial regulator of apical dominance. Proc. Natl. Acad. Sci. USA 2014, 111, 6092-6097. [CrossRef]

177. Tarancan, C.; Gonzalez-Grandio, E.; Oliveros, J.C.; Nicolas, M.; Cubas, P. A Conserved Carbon Starvation Response Underlies Bud Dormancy in Woody and Herbaceous Species. Front. Plant Sci. 2017, 8, 788. [CrossRef]

178. Barbier, F.; Péron, T.; Lecerf, M.; Perez-Garcia, M.D.; Barrière, Q.; Rolčík, J.; Boutet-Mercey, S.; Citerne, S.; Lemoine, R.; Porcheron, B.; et al. Sucrose is an early modulator of the key hormonal mechanisms controlling bud outgrowth in Rosa hybrida. J. Exp. Bot. 2015, 66, 2569-2582. [CrossRef]

179. Rabot, A.; Henry, C.; Ben Baaziz, K.; Mortreau, E.; Azri, W.; Lothier, J.; Hamama, L.; Boummaza, R.; Leduc, N.; Pelleschi-Travier, S.; et al. Insight into the role of sugars in bud burst under light in the rose. Plant Cell Physiol. 2012, 53, 1068-1082. [CrossRef]

180. Rabot, A.; Portemer, V.; Péron, T.; Mortreau, E.; Leduc, N.; Hamama, L.; Coutos-Thévenot, P.; Atanassova, R.; Sakr, S.; Le Gourrierec, J.; et al. Interplay of sugar, light and gibberellins in expression of Rosa hybrida vacuolar invertase 1 regulation. Plant Cell Physiol. 2014, 55, 1734-1748. [CrossRef]

181. Salam, B.B.; Malka, S.K.; Zhu, X.; Gong, H.; Ziv, C.; Teper-Bamnolker, P.; Ori, N.; Jiang, J.; Eshel, D. Etiolated stem branching is a result of systemic signaling associated with sucrose level. Plant Physiol. 2017, 175, 734-745. [CrossRef] [PubMed]

182. Fichtner, F.; Olas, J.J.; Feil, R.; Watanabe, M.; Krause, U.; Hoefgen, R.; Stitt, M.; Lunn, J.E. Functional Features of TREHALOSE-6PHOSPHATE SYNTHASE1, an Essential Enzyme in Arabidopsis. Plant Cell 2020, 32, 1949-1972. [CrossRef]

183. Fichtner, F.; Barbier, F.F.; Annunziata, M.G.; Feil, R.; Olas, J.J.; Mueller-Roeber, B.; Stitt, M.; Beveridge, C.A.; Lunn, J.E. Regulation of shoot branching in Arabidopsis by trehalose 6-phosphate. New Phytol. 2020. [CrossRef] [PubMed]

184. Bertheloot, J.; Barbier, F.; Boudon, F.; Perez-Garcia, M.D.; Péron, T.; Citerne, S.; Dun, E.; Beveridge, C.A.; Godin, C.; Sakr, S. Sugar availability suppresses the auxin-induced strigolactone pathway to promote bud outgrowth. New Phytol. 2020, 225, 866-879. [CrossRef] [PubMed]

185. Roman, H.; Girault, T.; Barbier, F.; Péron, T.; Brouard, N.; Pěnčík, A.; Novák, O.; Vian, A.; Sakr, S.; Lothier, J.; et al. Cytokinins are initial targets of light in the control of bud outgrowth. Plant Physiol. 2020, 172, 489-509. [CrossRef] [PubMed] 
186. Schippers, J.H.; Schmidt, R.; Wagstaff, C.; Jing, H.C. Living to die and dying to live: The survival strategy behind leaf senescence. Plant Physiol. 2015, 169, 914-930. [CrossRef]

187. Woo, H.R.; Masclaux-Daubresse, C.; Lim, P.O. Plant senescence: How plants know when and how to die. J. Exp. Bot. 2018, 69, 715-718. [CrossRef]

188. Ninan, A.S.; Grant, J.; Song, J.; Jameson, P.E. Expression of Genes Related to Sugar and Amino Acid Transport and Cytokinin Metabolism during Leaf Development and Senescence in Pisum sativum L. Plants 2019, 8, 76. [CrossRef]

189. Kumar, R.; Bishop, E.; Bridges, W.C.; Tharayil, N.; Sekhon, R.S. Sugar Partitioning and Source-Sink Interaction are Key Determinants of Leaf Senescence in Maize. Plant Cell Environ. 2019, 42, 2597-2611. [CrossRef]

190. Jan, S.; Abbas, N.; Ashraf, M.; Ahmad, P. Roles of potential plant hormones and transcription factors in controlling leaf senescence and drought tolerance. Protoplasma 2019, 256, 313-329. [CrossRef]

191. Wingler, A.; Roitsch, T. Metabolic regulation of leaf senescence: Interactions of sugar signalling with biotic and abiotic stress responses. Plant Biol. 2008, 10, 50-62. [CrossRef] [PubMed]

192. Wingler, A.; Masclaux-Daubresse, C.; Fischer, A.M. Sugars, senescence, and ageing in plants and heterotrophic organisms. J. Exp. Bot. 2009, 60, 1063-1066. [CrossRef]

193. Pourtau, N.; Jennings, R.; Pelzer, E.; Pallas, J.; Wingler, A. Effect of sugar-induced senescence on gene expression and implications for the regulation of senescence in Arabidopsis. Planta 2006, 224, 556-568. [CrossRef] [PubMed]

194. Dai, N.; Schaffer, A.; Petreikov, M.; Shahak, Y.; Giller, Y.; Ratner, K.; Levine, A.; Granot, D. Overexpression of Arabidopsis hexokinase in tomato plants inhibits growth, reduces photosynthesis, and induces rapid senescence. Plant Cell 1999, 11, 1253-1266.

195. Kelly, G.; David-Schwartz, R.; Sade, N.; Moshelion, M.; Levi, A.; Alchanatis, V.; Granot, D. The pitfalls of transgenic selection and new roles of AtHXK1: A high level of AtHXK1 expression uncouples hexokinase1-dependent sugar signaling from exogenous sugar. Plant Physiol. 2012, 159, 47-51. [CrossRef] [PubMed]

196. Xiao, W.; Sheen, J.; Jang, J.C. The role of hexokinase in plant sugar signal transduction and growth and development. Plant Mol. Biol. 2000, 44, 451-461. [CrossRef]

197. Van Doorn, W.G. Is the onset of senescence in leaf cells of intact plants due to low or high sugar levels? J. Exp. Bot. 2008, 59, 1963-1972. [CrossRef] [PubMed]

198. Wingler, A.; Delatte, T.L.; O'Hara, L.E.; Primavesi, L.F.; Jhurreea, D.; Paul, M.J.; Schluepmann, H. Trehalose 6-phosphate is required for the onset of leaf senescence associated with high carbon availability. Plant Physiol. 2012, 158, 1241-1251. [CrossRef]

199. Deprost, D.; Yao, L.; Sormani, R.; Moreau, M.; Leterreux, G.; Nicolaï, M.; Bedu, M.; Robaglia, C.; Meyer, C. The Arabidopsis TOR kinase links plant growth, yield, stress resistance and mRNA translation. EMBO Rep. 2007, 8, 864-870. [CrossRef]

200. Richmond, A.E.; Lang, A. Effect of Kinetin on Protein Content and Survival of Detached Xanthium Leaves. Science 1957, 125, 650-651. [CrossRef]

201. Jibran, R.; Hunter, D.A.; Dijkwel, P.P. Hormonal regulation of leaf senescence through integration of developmental and stress signals. Plant Mol. Biol. 2013, 82, 547-561. [CrossRef] [PubMed]

202. Markovich, O.; Steiner, E.; Kouřil, Š.; Tarkowski, P.; Aharoni, A.; Elbaum, R. Silicon promotes cytokinin biosynthesis and delays senescence in Arabidopsis and Sorghum. Plant Cell Environ. 2017, 40, 1189-1196. [CrossRef] [PubMed]

203. Khaskheli, A.J.; Ahmed, W.; Ma, C.; Zhang, S.; Liu, Y.; Li, Y.; Gao, J. RhERF113 Functions in Ethylene-Induced Petal Senescence by Modulating Cytokinin Content in Rose. Plant Cell Physiol. 2018, 59, 2442-2451. [CrossRef] [PubMed]

204. Okeefe, D.; Song, J.; Jameson, P.E. Isopentenyl Transferase and Cytokinin Oxidase/Dehydrogenase Gene Family Members are Differentially Expressed during Pod and Seed Development in Rapid-cycling Brassica. J. Plant Growth Regul. 2011, 30, 92-99. [CrossRef]

205. Edlund, E.; Novak, O.; Karady, M.; Ljung, K.; Jansson, S. Contrasting patterns of cytokinins between years in senescing aspen leaves. Plant Cell Environ. 2017, 40, 622-634. [CrossRef]

206. Lara, M.E.B.; Garcia, M.C.G.; Fatima, T.; Ehneß, R.; Lee, T.K.; Proels, R.; Tanner, W.; Roitsch, T. Extracellular invertase is an essential component of cytokinin-mediated delay of senescence. Plant Cell 2004, 16, 1276-1287. [CrossRef]

207. Jin, Y.; Ni, D.A.; Ruan, Y.L. Posttranslational elevation of cell wall invertase activity by silencing its inhibitor in tomato delays leaf senescence and increases seed weight and fruit hexose level. Plant Cell 2009, 21, 2072-2089. [CrossRef]

208. Liao, S.; Wang, L.; Li, J.; Ruan, Y.L. Cell wall invertase is essential for ovule development through sugar signaling rather than provision of carbon. Plant Physiol. 2020, 183, 1126-1144. [CrossRef]

209. Wu, L.; Ma, N.; Jia, Y.; Zhang, Y.; Feng, M.; Jiang, C.Z.; Ma, C.; Gao, J. An ethylene-induced regulatory module delays flower senescence by regulating cytokinin content. Plant Physiol. 2017, 173, 853-862. [CrossRef]

210. Balazadeh, S.; Riaño-Pachón, D.M.; Mueller-Roeber, B. Transcription factors regulating leaf senescence in Arabidopsis thaliana. Plant Biol. 2008, 10, 63-75. [CrossRef]

211. Zwack, P.J.; Robinson, B.R.; Risley, M.G.; Rashotte, A.M. Cytokinin response factor 6 negatively regulates leaf senescence and is induced in response to cytokinin and numerous abiotic stresses. Plant Cell Physiol. 2013, 54, 971-981. [CrossRef] [PubMed]

212. Janečková, H.; Husičková, A.; Ferretti, U.; Prčina, M.; Pilařová, E.; Plačková, L.; Pospíšil, P.; Doležal, K.; Špundová, M. The interplay between cytokinins and light during senescence in detached Arabidopsis leaves. Plant Cell Environ. 2018, 41, 1870-1885. [CrossRef] [PubMed]

213. Krieger-Liszkay, A.; Krupinska, K.; Shimakawa, G. The impact of photosynthesis on initiation of leaf senescence. Physiol. Plant. 2019, 166, 148-164. [CrossRef] 
214. Glanz-Idan, N.; Tarkowski, P.; Turečková, V.; Wolf, S. Root-shoot communication in tomato plants: Cytokinin as a signal molecule modulating leaf photosynthetic activity. J. Exp. Bot. 2019, 71, 247-257. [CrossRef] [PubMed]

215. Joshi, S.; Choukimath, A.; Isenegger, D.; Panozzo, J.; Spangenberg, G.; Kant, S. Improved wheat growth and yield by delayed leaf senescence using developmentally regulated expression of a cytokinin biosynthesis gene. Front. Plant Sci. 2019, 10, 1285. [CrossRef] [PubMed]

216. Lobo, A.K.M.; de Oliveira Martins, M.; Neto, M.C.L.; Machado, E.C.; Ribeiro, R.V.; Silveira, J.A.G. Exogenous sucrose supply changes sugar metabolism and reduces photosynthesis of sugarcane through the down-regulation of Rubisco abundance and activity. J. Plant Physiol. 2015, 179, 113-121. [CrossRef] [PubMed]

217. Shkolnik-Inbar, D.; Bar-Zvi, D. ABI4 mediates abscisic acid and cytokinin inhibition of lateral root formation by reducing polar auxin transport in Arabidopsis. Plant Cell 2010, 22, 3560-3573. [CrossRef] [PubMed]

218. Zhang, P.; Wang, W.Q.; Zhang, G.L.; Kaminek, M.; Dobrev, P.; Xu, J.; Gruissem, W. Senescence-inducible expression of isopentenyl transferase extends leaf life, increases drought stress resistance and alters cytokinin metabolism in cassava. J. Integr. Plant Biol. 2010, 52, 653-669. [CrossRef]

219. Ye, C.; Wu, S.; Kong, F.; Zhou, C.; Yang, Q.; Sun, Y.; Wang, B. Identification and characterization of an isopentenyltransferase (IPT) gene in soybean (Glycine max L.). Plant Sci. 2006, 170, 542-550. [CrossRef]

220. Fornara, F.; De Montaigu, A.; Sánchez-Villarreal, A.; Takahashi, Y.; Ver Loren van Themaat, E.; Huettel, B.; Davis, S.J.; Coupland, G. The GI-CDF module of Arabidopsis affects freezing tolerance and growth as well as flowering. Plant J. 2015, 81, 695-706. [CrossRef]

221. Yamaguchi, A.; Kobayashi, Y.; Goto, K.; Abe, M.; Araki, T. TWIN SISTER OF FT (TSF) acts as a floral pathway integrator redundantly with FT. Plant Cell Physiol. 2005, 46, 1175-1189. [CrossRef] [PubMed]

222. Parcy, F. Flowering: A time for integration. Int. J. Dev. Biol. 2004, 49, 585-593. [CrossRef] [PubMed]

223. Corbesier, L.; Lejeune, P.; Bernier, G. The role of carbohydrates in the induction of flowering in Arabidopsis thaliana: Comparison between the wild type and a starchless mutant. Planta 1998, 206, 131-137. [CrossRef]

224. Lejeune, P.; Bernier, G.; Requier, M.C.; Kinet, J.M. Sucrose increase during floral induction in the phloem sap collected at the apical part of the shoot of the long-day plant Sinapis alba L. Planta 1993, 190, 71-74. [CrossRef]

225. Micallef, B.J.; Haskins, K.A.; Vanderveer, P.J.; Roh, K.S.; Shewmaker, C.K.; Sharkey, T.D. Altered photosynthesis, flowering, and fruiting in transgenic tomato plants that have an increased capacity for sucrose synthesis. Planta 1995, 196, 327-334. [CrossRef]

226. Roldán, M.; Gómez-Mena, C.; Ruiz-García, L.; Salinas, J.; Martínez-Zapater, J.M. Sucrose availability on the aerial part of the plant promotes morphogenesis and flowering of Arabidopsis in the dark. Plant J. 1999, 20, 581-590. [CrossRef]

227. Ohto, M.A.; Onai, K.; Furukawa, Y.; Aoki, E.; Araki, T.; Nakamura, K. Effects of sugar on vegetative development and floral transition in Arabidopsis. Plant Physiol. 2001, 127, 252-261. [CrossRef]

228. Yang, L.; Xu, M.; Koo, Y.; He, J.; Poethig, R.S. Sugar promotes vegetative phase change in Arabidopsis thaliana by repressing the expression of MIR156A and MIR156C. Elife 2013, 2, e00260. [CrossRef]

229. Wahl, V.; Ponnu, J.; Schlereth, A.; Arrivault, S.; Langenecker, T.; Franke, A.; Feil, R.; Lunn, J.E.; Stitt, M.; Schmid, M. Regulation of flowering by trehalose-6-phosphate signaling in Arabidopsis thaliana. Science 2013, 339, 704-707. [CrossRef]

230. Zhao, M.L.; Ni, J.; Chen, M.S.; Xu, Z.F. Ectopic expression of Jatropha curcas TREHALOSE-6-PHOSPHATE PHOSPHATASE J causes late-flowering and Heterostylous phenotypes in Arabidopsis but not in Jatropha. Int. J. Mol. Sci. 2019, 20, 2165. [CrossRef]

231. Kataya, A.R.; Elshobaky, A.; Heidari, B.; Dugassa, N.F.; Thelen, J.J.; Lillo, C. Multi-targeted trehalose-6-phosphate phosphatase I harbors a novel peroxisomal targeting signal 1 and is essential for flowering and development. Planta 2020, 251, 1-14. [CrossRef] [PubMed]

232. Jin, S.; Kim, S.Y.; Ahn, J.H. TWIN SISTER OF FT (TSF) interacts with FRUCTOKINASE6 and inhibits its kinase activity in Arabidopsis. Front. Plant Sci. 2017, 8, 1807. [CrossRef]

233. Bonhomme, F.; Kurz, B.; Melzer, S.; Bernier, G.; Jacqmard, A. Cytokinin and gibberellin activate SaMADS A, a gene apparently involved in regulation of the floral transition in Sinapis alba. Plant J. 2000, 24, 103-111. [CrossRef] [PubMed]

234. D’Aloia, M.; Bonhomme, D.; Bouché, F.; Tamseddak, K.; Ormenese, S.; Torti, S.; Coupland, G.; Périlleux, C. Cytokinin promotes flowering of Arabidopsis via transcriptional activation of the FT paralogue TSF. Plant J. 2011, 65, 972-979. [CrossRef] [PubMed]

235. Bartrina, I.; Jensen, H.; Novák, O.; Strnad, M.; Werner, T.; Schmülling, T. Gain-of-function mutants of the cytokinin receptors AHK2 and AHK3 regulate plant organ size, flowering time and plant longevity. Plant Physiol. 2017, 173, 1783-1797. [CrossRef] [PubMed]

236. Burr, C.A.; Sun, J.; Yamburenko, M.V.; Willoughby, A.; Hodgens, C.; Boeshore, S.L.; Elmore, A.; Atkinson, J.; Nimchuk, Z.L.; Bishopp, A.; et al. The HK5 and HK6 cytokinin receptors mediate diverse developmental pathways in rice. Development 2020, 147, dev191734. [CrossRef] [PubMed]

237. Villar, L.; Lienqueo, I.; Llanes, A.; Rojas, P.; Perez, J.; Correa, F.; Sagredo, B.; Masciarelli, O.; Luna, V.; Almada, R. Comparative transcriptomic analysis reveals novel roles of transcription factors and hormones during the flowering induction and floral bud differentiation in sweet cherry trees (Prunus avium L. cv. Bing). PLoS ONE 2020, 15, e0230110. [CrossRef] 